\title{
Controlled Cortical Impact Traumatic Brain Injury in 3xTg-AD Mice Causes Acute Intra-Axonal Amyloid- $\beta$ Accumulation and Independently Accelerates the Development of Tau Abnormalities
}

\author{
Hien T. Tran, ${ }^{1}$ Frank M. LaFerla, ${ }^{4}$ David M. Holtzman, ${ }^{1,2,3}$ and David L. Brody ${ }^{1,3}$ \\ ${ }^{1}$ Department of Neurology, ${ }^{2}$ Department of Developmental Biology and Anatomy, and ${ }^{3}$ Hope Center for Neurological Disorders, Washington University in \\ St. Louis, St. Louis, Missouri 63110, ${ }^{4}$ Department of Neurobiology and Behavior, University of California, Irvine, California 92697
}

\begin{abstract}
Alzheimer's disease $(\mathrm{AD})$ is a neurodegenerative disorder characterized pathologically by progressive neuronal loss, extracellular plaques containing the amyloid- $\beta(\mathrm{A} \beta)$ peptides, and neurofibrillary tangles composed of hyperphosphorylated tau proteins. $\mathrm{A} \beta$ is thought to act upstream of tau, affecting its phosphorylation and therefore aggregation state. One of the major risk factors for AD is traumatic brain injury (TBI). Acute intra-axonal $\mathrm{A} \beta$ and diffuse extracellular plaques occur in $\sim 30 \%$ of human subjects after severe TBI. Intra-axonal accumulations of tau but not tangle-like pathologies have also been found in these patients. Whether and how these acute accumulations contribute to subsequent $\mathrm{AD}$ development is not known, and the interaction between $\mathrm{A} \beta$ and tau in the setting of TBI has not been investigated. Here, we report that controlled cortical impact TBI in 3xTg-AD mice resulted in intra-axonal A $\beta$ accumulations and increased phospho-tau immunoreactivity at $24 \mathrm{~h}$ and up to $7 \mathrm{~d}$ after TBI. Given these findings, we investigated the relationship between $\mathrm{A} \beta$ and tau pathologies after trauma in this model by systemic treatment of Compound $\mathrm{E}$ to inhibit $\gamma$-secretase activity, a proteolytic process required for $\mathrm{A} \beta$ production. Compound $\mathrm{E}$ treatment successfully blocked posttraumatic $\mathrm{A} \beta$ accumulation in these injured mice at both time points. However, tau pathology was not affected. Our data support a causal role for TBI in acceleration of $\mathrm{AD}$-related pathologies and suggest that TBI may independently affect $\mathrm{A} \beta$ and tau abnormalities. Future studies will be required to assess the behavioral and long-term neurodegenerative consequences of these pathologies.
\end{abstract}

\section{Introduction}

Traumatic brain injury (TBI) can increase the risk for subsequent development of dementia of the Alzheimer's type (Mortimer et al., 1991; Nemetz et al., 1999; Plassman et al., 2000; Fleminger et al., 2003). Pathological hallmarks of Alzheimer's disease (AD) are extracellular plaques containing the amyloid- $\beta$ (A $\beta)$ peptides and neurofibrillary tangles (NFTs) containing hyperphosphorylated tau proteins.

In mouse models of $\mathrm{AD}, \mathrm{A} \beta$ pathology appears to be upstream of tau pathology. Three lines of experimental evidence support this relationship. First, intracerebral injections of aggregated $\mathrm{A} \beta$

\footnotetext{
Received Feb. 17, 2011; revised May 11, 2011; accepted May 15, 2011.

Author contributions: H.T.T., D.M.H., and D.L.B. designed research; H.T.T. and D.L.B. performed research; F.M.L and D.M.H. contributed unpublished reagents/analytic tools; H.T.T. and D.L.B. analyzed data; H.T.T. and D.L.B. wrote the paper.

This work was supported by NIH Grants R01 NS065069 (D.L.B.), K08 NS049237 (D.L.B.), and AG13956 (D.M.H.); a Burroughs Wellcome Career Award in the Biomedical Sciences (D.L.B.); the Thrasher Research Fund (D.L.B.); the Cure Alzheimer's Fund (D.M.H.); and NIH Neuroscience Blueprint Core Grant P30 NS057105 to Washington University. We thank Drs. J. R. Cirrito, J. S. Kim, and C. L. Mac Donald and T. J. Esparza for methodological assistance; R. H. Baloh, R. Bennett, J. R. Cirrito, T. J. Esparza, C. L. Mac Donald, and T. Malone for critical review of this manuscript; and Peter Davies and Eli Lilly and Co. for monoclonal antibodies.

The authors declare no competing financial interests.

Correspondence should be addressed to Dr. David L. Brody, Washington University School of Medicine, $660 \mathrm{~S}$. Euclid Avenue, Campus Box 8111, St. Louis, M0 63110. E-mail: brodyd@neuro.wustl.edu.

DOI:10.1523/JNEUROSCI.0858-11.2011

Copyright $\odot 2011$ the authors $\quad 0270-6474 / 11 / 319513-13 \$ 15.00 / 0$
}

increased tau phosphorylation and therefore numbers of NFTs in $\mathrm{Tau}_{\mathrm{P} 310 \mathrm{~L}}$ transgenic mice at both local and distant regions (Gotz et al., 2001). Second, double-transgenic mice expressing both mutant APP and tau developed greater tau pathology than single tau transgenic mice (Lewis et al., 2001; Perez et al., 2005; Hurtado et al., 2010). Third, intracerebral injections of anti- $A \beta$ antibodies in 3xTg-AD mice reduced both $A \beta$ and tau pathology. $A \beta$ pathology then recurred, followed by later recurrence of tau pathology (Oddo et al., 2004).

On the other hand, the human pathological literature suggests that $A \beta$ and tau pathologies may be independent in the setting of TBI, or at least that the relationship may be more complex. First, in single severe TBI, intra-axonal $\mathrm{A} \beta$ and diffuse extracellular plaques occurred in about 30\% of subjects (Roberts et al., 1991, 1994; Uryu et al., 2007). Intra-axonal accumulations of total and phospho-tau, but not true NFT pathology, have been documented in a smaller number of cases (C. Smith et al., 2003; Ikonomovic et al., 2004; Uryu et al., 2007). In repetitive concussive TBI resulting in dementia pugilistica or chronic traumatic encephalopathy, the opposite relationship was found; $100 \%$ of cases reported to date have had widespread NFTs, but a smaller subset had $\mathrm{A} \beta$ pathology (Corsellis and Brierley, 1959; Corsellis, 1989; Roberts et al., 1990; Tokuda et al., 1991; Geddes et al., 1996, 1999; Schmidt et al., 2001; McKee et al., 2009). 
Even when both pathologies were present, there was no indication that they colocalized.

To investigate the relationship between $\mathrm{A} \beta$ and tau pathologies in the setting of TBI, we performed controlled cortical impact TBI in a mouse model of Alzheimer's disease, called 3xTg-AD. In the absence of injury, these mice develop intracellular $\mathrm{A} \beta$ accumulation starting at 2 months, intracellular tau immunoreactivity at 6 months, extracellular $A \beta$ deposition at 15-26 months, and tau-containing neurofibrillary tangles at 26 months (Oddo et al., 2003, 2006; Mastrangelo and Bowers, 2008). Here, we show that controlled cortical impact TBI independently results in intraaxonal $\mathrm{A} \beta$ and tau accumulation and increased tau phosphorylation in 3xTg-AD mice. This model may be a useful tool for many mechanistic and preclinical therapeutic investigations into the association between TBI and Alzheimer's disease.

\section{Materials and Methods}

Animals. We used 5- to 7-month-old homozygous 3xTg-AD mice (Oddo et al., 2003) of both sexes on a B6/SJV129 background and wild-type $\mathrm{B} 6 / \mathrm{SJL}$ mice. $3 \mathrm{xTg}-\mathrm{AD}$ mice used in these experiments were derived from founders received from the LaFerla laboratory in 2007. A $\beta$ and tau pathologies have been stable since that time, with no evidence of drift. Mice were housed in standard cages in a $12 \mathrm{~h}$ light/dark cycle and given food and water ad libitum. All experiments were approved by the animal studies committee at Washington University in St Louis.

Controlled cortical impact experimental TBI. The experimental TBI methods used in this study were performed as described previously (Brody et al., 2007; Mac Donald et al., 2007b). Briefly, mice were anesthetized with isoflurane (5\% induction, $2 \%$ maintenance) and placed on a stereotaxic frame. After a midline skin incision, a $5 \mathrm{~mm}$ left lateral craniotomy was made using a motorized drill. Controlled cortical impact was produced with an electromagnetic impact device using a 3-mmdiameter metal tip. The impact was centered at $2.7 \mathrm{~mm}$ lateral to midline and $3.0 \mathrm{~mm}$ anterior to lambda. Injury severities of $1.0 \mathrm{~mm}(n=6), 1.5$ $\mathrm{mm}(n=5)$, and $2.0 \mathrm{~mm}(n=48$ total in all experiments) below the dura were chosen to model mild, mild-moderate, and moderate injuries, respectively. After injury, the impact site was covered with a plastic skull cap, skin was sutured, and mice were allowed to recover on a heated pad. Mice were kept at $37^{\circ} \mathrm{C}$ via a rectal temperature probe and feedback temperature controller throughout the duration of the surgery (Cell MicroControls). Temperature control is important because hypothermia alone has been reported to cause tau accumulation and hyperphosphorylation (Planel et al., 2004). Sham mice underwent the same surgical procedure including anesthesia and craniotomy but were not injured.

Antibodies. Antibodies used are listed in Table 1. To avoid using antimouse secondary antibodies on injured tissues, most monoclonal antibodies were conjugated to biotin or directly labeled. 3D6 was biotinylated with NHS-LC-biotin from Pierce. Conjugation of 3D6 to Alexa Fluor 596 was done a via commercially available kit (A20185; Invitrogen).

Immunohistochemistry and double immunofluorescence. Immunohistochemical studies were done on paraformaldehyde-fixed, sucroseequilibrated $50 \mu \mathrm{m}$ cryostat sections, as described previously (Mac Donald et al., 2007a,b). All sections were washed with Tris-buffered saline (TBS) between applications of antibody solutions. Antigen retrieval with $70 \%$ formic acid ( $3 \mathrm{~min}$ ) was performed for $\mathrm{A} \beta$ and phospho-tau staining. Nonspecific binding was blocked by incubation in TBS containing $0.25 \%$ Triton X (TBS-X) and 3\% nonfat dry milk (monoclonal antibodies) or 3\% serum (polyclonal antibodies) or 5\% BSA (phospho-tau antibodies). The primary antibody was diluted in $1 \%$ nonfat dry milk, $1 \%$ serum, or $1 \%$ BSA in TBS-X. Antibodies were 3D6 $(1 \mu \mathrm{g} / \mathrm{ml})$, pan-A $\beta$ $(1 \mu \mathrm{g} / \mathrm{ml}), \mathrm{A} \beta 40(0.5 \mu \mathrm{g} / \mathrm{ml}), \mathrm{A} \beta 42(5 \mu \mathrm{g} / \mathrm{ml}), \mathrm{APP}(0.5 \mu \mathrm{g} / \mathrm{ml})$, neurofilament $(0.5 \mu \mathrm{g} / \mathrm{ml})$, HT7 $(0.2 \mu \mathrm{g} / \mathrm{ml})$, polyclonal tau $(1 \mu \mathrm{g} / \mathrm{ml})$, polyclonal phospho-tau antibodies $(1 \mu \mathrm{g} / \mathrm{ml})$, and PHF1 (1:1000) (Table 1). Bound antibodies were detected with biotinylated secondary antibodies, except for 3D6, which was biotinylated. The horseradish peroxidase method (ABC Elite kit, PK6100; Vector Laboratories) and DAB were used for visualization of bound antibodies.
Table 1. Summary of antibodies used in this study

\begin{tabular}{|c|c|c|c|c|}
\hline Protein & Antibody & Epitope & Host/application & Source \\
\hline \multirow[t]{7}{*}{$A \beta$} & $3 D 6$ & $\begin{array}{l}\text { aa } 1-5 \text { requiring } \\
\text { free } N \text { terminus }\end{array}$ & Mouse/IHC, ELISA & Eli Lilly and Co. \\
\hline & $\mathrm{m} 266$ & aа $13-28$ & Mouse/ELISA & Eli Lilly and Co. \\
\hline & $2 \mathrm{G} 3$ & aа $35-40$ & Mouse/ELISA & Eli Lilly and $\mathrm{Co}$. \\
\hline & $21 F 12$ & aa $33-42$ & Mouse/ELISA & Eli Lilly and Co. \\
\hline & $\operatorname{pan} A \beta$ & aa $15-30$ & Rabbit/IHC & Invitrogen \\
\hline & $A \beta 40$ & aа $34-40$ & Rabbit/IHC & Invitrogen \\
\hline & $A \beta 42$ & aа $36-42$ & Rabbit/IHC & Chemicon \\
\hline APP & APP & Full-length, C terminal & Rabbit//HC, WB & Invitrogen \\
\hline \multirow[t]{12}{*}{ Tau } & HT7 & panTau & Mouse/IHC & Pierce \\
\hline & pAb Tau & panTau & Sheep/IHC & Pierce \\
\hline & Tau46 & panTau & Mouse/WB & Cell Signaling \\
\hline & AT8 & pS199, pS202, pT205 & Mouse/WB & Pierce \\
\hline & AT100 & pS212, pT214 & Mouse/WB & Pierce \\
\hline & AT180 & pT231 & Mouse/WB & Autogen Bioclear \\
\hline & S199 & pS199 & Rabbit/IHC & Invitrogen \\
\hline & T205 & pT205 & Rabbit/IHC & Invitrogen \\
\hline & T231 & pT231 & Rabbit/IHC & Invitrogen \\
\hline & S396 & pS396 & Rabbit/IHC & Invitrogen \\
\hline & $\$ 422$ & pS422 & Rabbit/IHC & Invitrogen \\
\hline & PHF1 & pS396/pS404 & Mouse/IHC & Dr. P. Davies \\
\hline Neurofilament & NF-L & NF-L 68kD & Mouse/IHC & Sigma \\
\hline Tubulin & $\alpha$-Tubulin & $\alpha$-Tubulin/C terminal & Mouse/WB & Sigma \\
\hline
\end{tabular}

aa, Amino acids; IHC, immunohistochemistry; WB, Western blot.

In double-labeling studies, primary antibodies were sequentially applied, followed by Alexa Fluor-conjugated secondary antibodies except for 3D6, which was conjugated to Alexa Fluor 596. Images were obtained using LSM 5 Pascal software (Zeiss Physiology Software) coupled to an LSM Pascal Vario 2 RGB confocal system (Zeiss).

Preparation of tissue homogenates for $A \beta$ detection by human-specific ELISAs. Separate groups of sham $(n=7)$ and TBI $(2.0 \mathrm{~mm}, n=8)$ mice were killed at $24 \mathrm{~h}$ after surgery; hippocampi ipsilateral and contralateral to the impact site (including fimbria and surrounding white matter tracts) were dounce homogenized in TBS $(1: 10 \mathrm{w} / \mathrm{v})$. Supernatants were kept, and pellets were subsequently sonicated in a 1:5 w/v solution of 100 mM sodium carbonate, $\mathrm{pH} 11$, containing $50 \mathrm{~mm}$ sodium chloride (carbonate lysates). Finally, remaining pellets were homogenized in 1:5 w/v $5 \mathrm{M}$ guanidine hydrochloride, rotated at room temperature for 3-4 h (guan lysates). All buffers used for homogenization contained protease and phosphatase inhibitor mixtures (Roche). Supernatants and pellets from all tissue suspensions were obtained by spinning at $13,300 \times g$ for $20 \mathrm{~min}$ at $4^{\circ} \mathrm{C}$. Protein concentrations were determined via the BCA method (Pierce Biotech). TBS, carbonate, and guanidine lysates prepared above were tested for $A \beta$ contents using a human-specific $A \beta$ ELISA, as described (Cirrito et al., 2003; Kang et al., 2007). Capture antibodies were $\mathrm{m} 266$ for the total $\mathrm{A} \beta_{1-\mathrm{x}}$ ELISA, $2 \mathrm{G} 3$ for the $\mathrm{A} \beta_{1-40}$ ELISA, and $21 \mathrm{~F} 12$ for the $A \beta_{1-42}$ ELISA. The detection antibody was 3D6-biotin. These antibodies were gifts from Eli Lilly and Co.

Preparation of tissue homogenates for tau Western blotting and ELISAs. Separate groups of sham $(n=7)$ and injured $(2.0 \mathrm{~mm}, n=8) 3 \mathrm{xTg}-\mathrm{AD}$ mice were killed at $24 \mathrm{~h}$ by rapid decapitation. Bilateral hippocampi were dissected, immediately frozen, and stored at $-80^{\circ} \mathrm{C}$. Frozen hippocampi were homogenized in modified RIPA buffer containing protease and phosphatase inhibitor mixtures (Roche), as described (Cirrito et al., 2003). After preclearing samples with protein-G Sepharose beads to remove endogenous mouse IgG, equal amounts of samples were electrophoresed on 10\% BisTris NUPAGE gels (Invitrogen). After transfer, 0.2$\mu \mathrm{m}$-pore nitrocellulose membranes were blocked with $5 \%$ nonfat dry milk in $50 \mathrm{~mm}$ Tris, pH 7.6, buffer containing $150 \mathrm{~mm} \mathrm{NaCl}$ and $0.1 \%$ Tween 20 (TBS-T) for $1 \mathrm{~h}$, and probed with AT8 (1:1000), AT100 (1: $1000)$, or AT180 (1:1000) in 5\% BSA TBS-T overnight at $4^{\circ} \mathrm{C}$. Sheep- $\alpha-$ mouse HRP (1:12,000; GE Healthcare) and the ECL Advance Western Blotting kit (GE Healthcare) were used to detect bound antibodies. Blots were stripped and reprobed for total tau using Tau46 antibody (1:1000). 

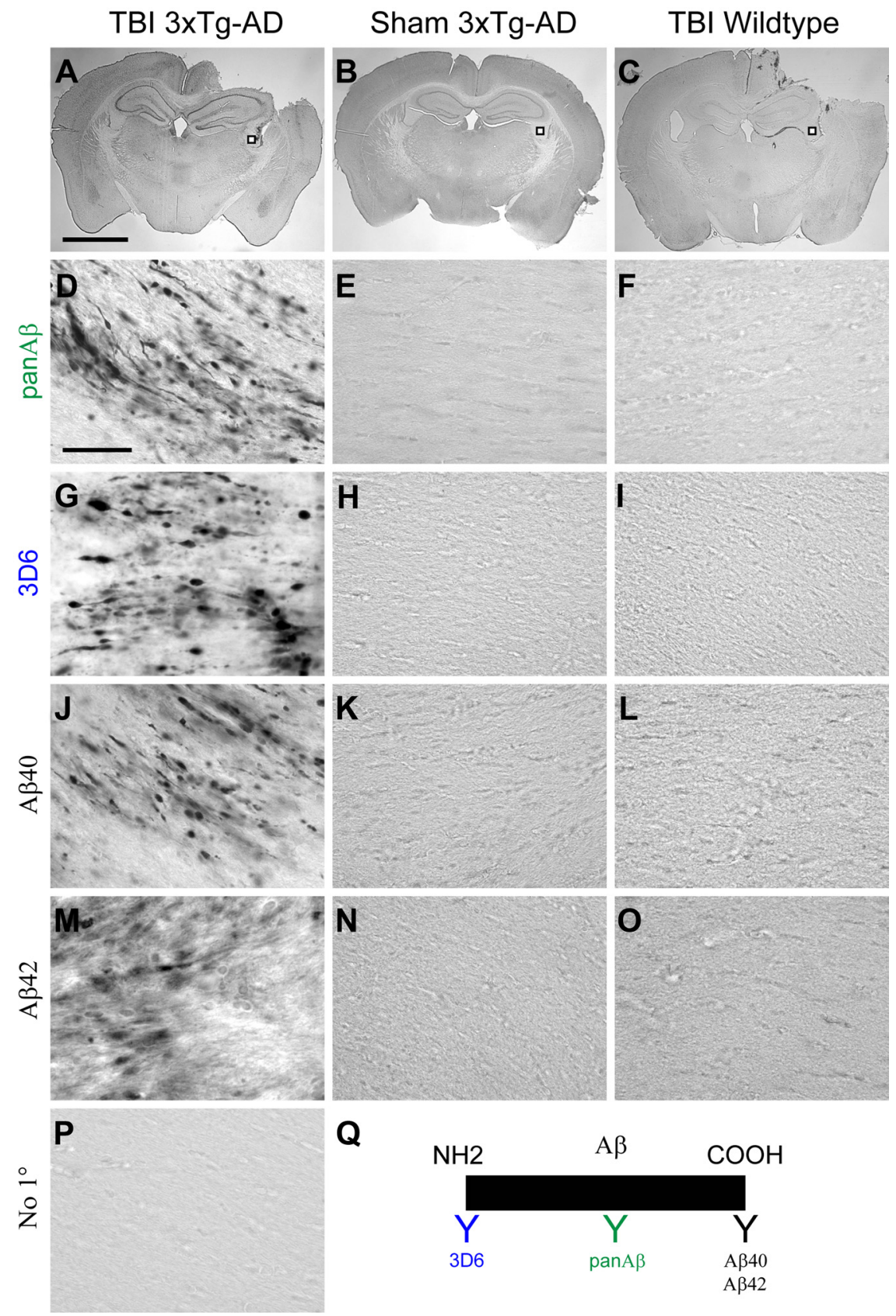

Q

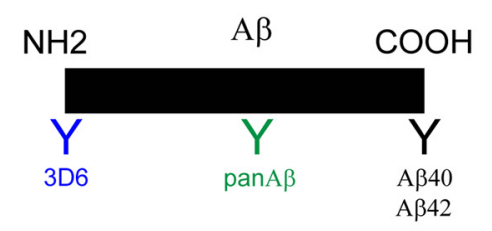

Figure 1. Controlled cortical impact TBI caused $A \beta$ accumulation in ipsilateral fimbria/fornix of young $3 x T g-A D$ mice. $A-C, A \beta$ immunohistochemistry from an injured 3xTg-AD mouse, a sham 3xTg-AD mouse, and an injured wild-type mouse, respectively. Scale bar, $2 \mathrm{~mm}$. D-0, Higher magnification of the ipsilateral fimbria/fornix ( $\boldsymbol{A}-\boldsymbol{C}$, boxes). Scale bar, $50 \mu \mathrm{m}$. The presence of intra-axonal $A \beta$ in the ipsilateral fimbria/fornix of a moderately injured $3 \times \mathrm{Tg}-A D$ mouse was confirmed using pan $A \beta$, a polyclonal antibody against amino acids $15-30$ of $A \beta(\boldsymbol{D}-\boldsymbol{F}) ; 3 \mathrm{D} 6$, a monoclonal $\mathrm{N}$-terminus antibody against amino acids $1-5$ of $A \beta(\mathbf{G}-\boldsymbol{I})$; $A \beta_{40}$, a polyclonal $C$-terminus antibody against amino acids $35-40$ of $A \beta(J-L)$; and $A \beta_{42}$, a polyclonal $C$-terminus antibody against amino acids $35-42$ of $A \beta(M-0)$. No $A \beta$ immunoreactivity was observed in sham 3xTg-AD mice and injured wild-type mice. $\boldsymbol{P}$, No $A \beta$ immunoreactivity was observed in injured 3xTg-AD mice when primary antibody was omitted. $\boldsymbol{Q}$, Schematic of anti-A $\beta$ antibodies used.

Blots were scanned, and densitometry was performed via Image J (NIH). Total and phospho-S199 tau ELISAs were performed per the manufacturer's instructions (Invitrogen).

Preparation of tissue homogenates for Western blotting of APP. Bilateral cerebellar tissue was homogenized in modified RIPA buffer containing protease inhibitor mixtures (Roche), as described (Cirrito and Holtzman, 2003). Protein concentrations were determined via the BCA method (Pierce Biotech). Equal amounts of samples were electrophoresed on $4-12 \%$ BisTris NuPAGE gels (Invitrogen) and transferred to
0.2- $\mu \mathrm{m}$-pore nitrocellulose membrane. After transfer, membranes were blocked in 3\% nonfat dry milk in TBS-T for $1 \mathrm{~h}$ at room temperature. After washing in TBS-T three times, 5 min each, membranes were incubated with polyclonal APP antibody $(0.25 \mu \mathrm{g} / \mathrm{ml})$ in blocking buffer overnight at $4^{\circ} \mathrm{C}$. Bound antibodies were detected with HRP-conjugated donkey- $\alpha$-rabbit IgG (1:10,000; GE Healthcare) and the ECL Advance Western Blotting detection kit (GE Healthcare). Blots were stripped and reprobed with anti- $\alpha$-tubulin (1 $\mu \mathrm{g} / \mathrm{ml})$ for loading control. Images were taken on film and scanned.

Compound E treatment. To prevent posttraumatic intra-axonal $\mathrm{A} \beta$ accumulation, mice were treated with intraperitoneal injections of vehicle or Compound $\mathrm{E}(\mathrm{CmpE})$, a smallmolecule inhibitor of $\gamma$-secretase $(10 \mathrm{mg} / \mathrm{kg}$; Axxora) (Seiffert et al., 2000; Olson et al., 2001; Grimwood et al., 2005; Yang et al., 2008; Yan et al., 2009). One group of mice received $\mathrm{CmpE}$ $(n=8)$ or $0.8 \%$ DMSO vehicle $(n=7)$ starting at $1 \mathrm{~h}$ before injury, then again at 5,11 , and $17 \mathrm{~h}$ after injury. These mice were killed $24 \mathrm{~h}$ after injury. Another group of mice received 4 CmpE $(n=7)$ or vehicle $(n=7)$ injections in the first $24 \mathrm{~h}$ as noted above, followed by injections twice daily until $7 \mathrm{~d}$ after injury. A total of $10 \mathrm{mg} / \mathrm{kg}$ Compound $\mathrm{E}$ was used because this dose has been shown to inhibit cortical $\gamma$-secretase activity in guinea pigs by $71 \pm 4 \%$, measured ex vivo (Grimwood et al., 2005). Furthermore, the frequent dosing regimen was used because of the short half-life of Compound E: 5-6 h (Yan et al., 2009). Last, this relatively high dose was also chosen because of the presence of the presenilin1 (PS1) M146L mutation in $3 \times \mathrm{Tg}-\mathrm{AD}$ mice, as PS1 mutations have been shown to have diminished response to $\gamma$-secretase inhibition (Czirr et al., 2007). Mice tolerated these dosing regimens well without additional weight loss, lethargy, or unexpected mortality.

Stereological quantification. Stereological methods were available via StereoInvestigator version 8.2 software. All assessments were made by a single investigator (H.T.T.) blinded to injury status and treatment regimens of experimental animals. The optical fractionator method was used for quantification of total numbers of markers of interest per cubic millimeter of tissue. Details on this stereological method have been described (Mac Donald et al., 2007a). Briefly, for quantification of $A \beta_{40^{-}}$ positive axonal varicosities in ipsilateral fimbria and tau-positive somata in ipsilateral amygdala, a $200 \times 200 \mu \mathrm{m}$ sampling grid and a $75 \times 75 \mu \mathrm{m}$ counting frame were used. For quantification of total tau, APP, $\operatorname{pan} A \beta$, and phospho-S199-positive puncta in ipsilateral fimbria, a $300 \times 300 \mu \mathrm{m}$ grid and a $40 \times 40 \mu \mathrm{m}$ counting frame were used. For PHF1-positive puncta in the fimbria, a $200 \times 200 \mu \mathrm{m}$ grid and a $50 \times 50 \mu \mathrm{m}$ counting frame were used. A dissector height of $15 \mu \mathrm{m}$ and guard zones of $2.5 \mu \mathrm{m}$ were used for all measurements. Four sections per mouse, each separated by $300 \mu \mathrm{m}$, were used for these estimations. These sections spanned approximately bregma -1.06 to $-1.96 \mathrm{~mm}$ (Franklin and Paxinos, 1997). The spherical probe (also known as "space balls") method was used for quantification of the total length of tau immuno- 
reactive processes in the dorsal contralateral CA1 region (Mouton et al., 2002). A sampling grid of $250 \times 250 \mu \mathrm{m}$ and a hemispherical probe with $17 \mu \mathrm{m}$ radius were used. Three sections per mouse from approximately bregma -1.46 to $-2.06 \mathrm{~mm}$ were used for this quantification.

Statistical methods. All data were analyzed using Prism 5.0 (GraphPad Software). ShapiroWilk normality tests were used to assess the normal distribution of each data set. MannWhitney $U$ tests were used to compare levels of $\mathrm{A} \beta$ and phospho-tau in hippocampal lysates of injured and sham $3 \mathrm{xTg}$-AD mice, since the distribution of data was not normal. For pairwise comparisons of quantitative immunochemical data (e.g., injured vs sham), one-sided Student's $t$ tests were used in these cases because unidirectional hypotheses were prespecified. For changes of either $A \beta$ or tau pathology as a function of injury severities, one-way ANOVAs with Newman-Keuls post tests were used. Values are means \pm SEM. Statistical significance was set to $p<0.05$.

\section{Results}

Intra-axonal $A \boldsymbol{\beta}$ accumulation after $\mathrm{TBI}$ in 3xTg-AD mice

Acute intra-axonal $A \beta$ accumulation is a prevalent feature of human traumatic axonal injury (D. H. Smith et al., 2003; Uryu et al., 2007; Chen et al., 2009). Because of the age-related intra-axonal $\mathrm{A} \beta$ accumulation in $3 \mathrm{xTg} \mathrm{AD}$ mice, we hypothesized that these animals would be useful in the assessment of TBI-related axonal A $\beta$ pathology. More specifically, we hypothesized that experimental TBI would accelerate intraaxonal $\mathrm{A} \beta$ pathology in young $3 \mathrm{xTg}-\mathrm{AD}$ mice. To test this hypothesis, we subjected these mice to controlled cortical impact TBI, as detailed (Brody et al., 2007). Mice were subjected to moderately severe injury: 2.0 $\mathrm{mm}$ below the dura. This resulted in significant hippocampal damage and behavioral deficits but low mortality, as described (Brody et al., 2007). Mice were killed at $24 \mathrm{~h}$ after TBI; their brains were then processed and examined immunohistochemically for $\mathrm{A} \beta$ pathology. Negative controls included age-matched, sham 3xTg-AD mice (which underwent the same anesthesia and surgical procedures but were not injured), injured wild-type B6/SJL mice $(2.0 \mathrm{~mm})$, and omission of primary antibodies. The positive controls for $\mathrm{A} \beta$ staining were brain slices from 20-month-old PDAPP mice (Games et al., 1995).

We found $\mathrm{A} \beta$ accumulations in pericontusional white matter of injured, young $3 \times \mathrm{Tg}-\mathrm{AD}$ mice. The ipsilateral fimbria/fornix appeared to have the most prominent $\mathrm{A} \beta$ accumulation (Fig. $1 A$ ). These $\mathrm{A} \beta$ accumulations had spheroidal and "beads-on-astring" morphologies, consistent with the morphology of injured axons (Fig. $1 D, G, J, M$ ). The specificity of this $\mathrm{A} \beta$ staining was confirmed with four $\mathrm{A} \beta$-specific antibodies: pan- $\mathrm{A} \beta$ against $\mathrm{A} \beta_{15-30}$ (Fig. $1 D$ ), monoclonal $3 \mathrm{D} 6$ against $\mathrm{A} \beta_{1-5}$ (Fig. $1 G$ ), polyclonal C-terminal antibody against $\mathrm{A} \beta_{35-40}$ (Fig. $1 \mathrm{~J}$ ), and polyclonal C-terminal antibody against $\mathrm{A} \beta_{35-42}$ (Fig. $1 M$ ). No $\mathrm{A} \beta$ staining was observed when primary antibodies were omitted
B

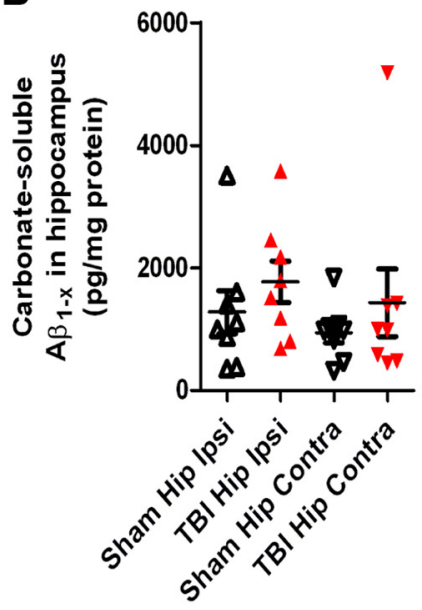

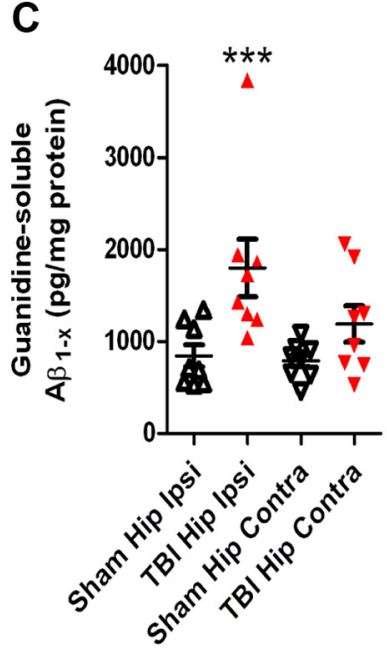

D

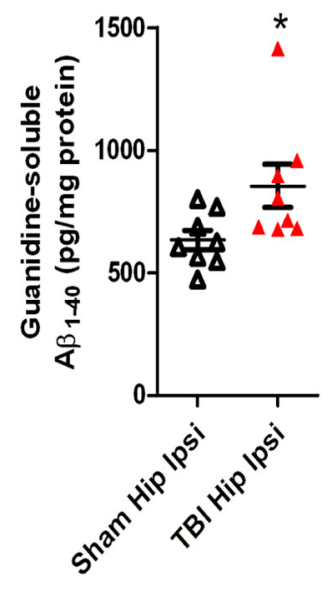

$\mathbf{E}$

Figure 2. Controlled cortical impact TBI resulted in increased levels of relatively insoluble $A \beta$ in $3 \times T g-A D$ mice. Ipsilateral (Ipsi) and contralateral (Contra) hippocampal tissues of injured ( $2.0 \mathrm{~mm}$ ) and sham 3xTg-AD mice were sequentially homogenized in TBS, carbonate, d guanidine buffers. TBS and carbonate lysates contain mostly soluble $A \beta$ species; guanidine lysates are composed of relatively insoluble carbonate lysates of ipsilateral and contralateral hippocampi of sham and injured mice. $C$, Total $A \beta$ levels in guanidine lysates of

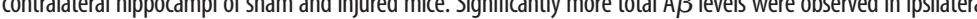
in guanidinelysates of ipsilateral hippocampi of sham and injured mice Significantlymore $A \beta_{1-40}$ and a trend toward an increase in $A \beta_{1-42}$ were observed in ipsilateral guanidine hippocampal lysates of injured compared with sham mice $\left({ }^{*} p=0.013\right.$; ns, not significant; MannWhitney $U$ test). $n=7-8$ mice per group. Error bars represent mean \pm SEM.

(Fig. 1P). No such axonal $\mathrm{A} \beta$ pathology was observed in sham (noninjured), age-matched 3xTg-AD mice (Fig. $1 B, E, H, K, N)$, nor in injured wild-type mice (Fig. $1 C, F, I, L, O)$. A $\beta$ was also observed in pericontusional hippocampal commissure, corpus callosum, and the external capsule of injured 3xTg-AD mice, although to a lesser extent than the fimbria/fornix (data not shown).

To further confirm the immunohistochemical findings, humanspecific $\mathrm{A} \beta_{1-\mathrm{x}}, \mathrm{A} \beta_{1-40}$, and $\mathrm{A} \beta_{1-42}$ ELISAs were used to assess $\mathrm{A} \beta$ levels in hippocampal lysates of these moderately injured and sham 3xTg-AD mice. Both ipsilateral and contralateral hippocampi were assessed. These tissues were subjected to serial homogenization in TBS, carbonate, and 5M guanidine. This serial homogenization method produces extracts enriched in soluble $\mathrm{A} \beta$ from the extracellular compartment, soluble $\mathrm{A} \beta$ from intracellular compartments, and residual insoluble $A \beta$, respectively. Although there were similar levels of total $\mathrm{A} \beta\left(\mathrm{A} \beta_{1-\mathrm{x}}\right)$ in TBS and carbonate lysates in both ipsilateral and contralateral hip- 
Sham
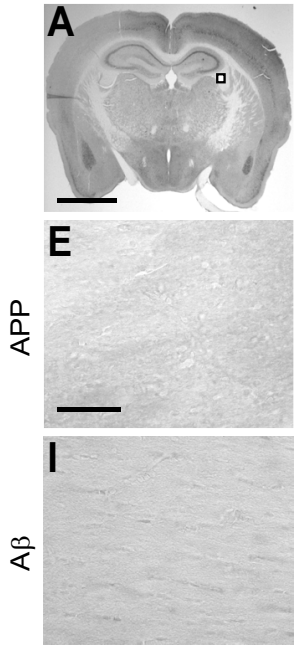

M
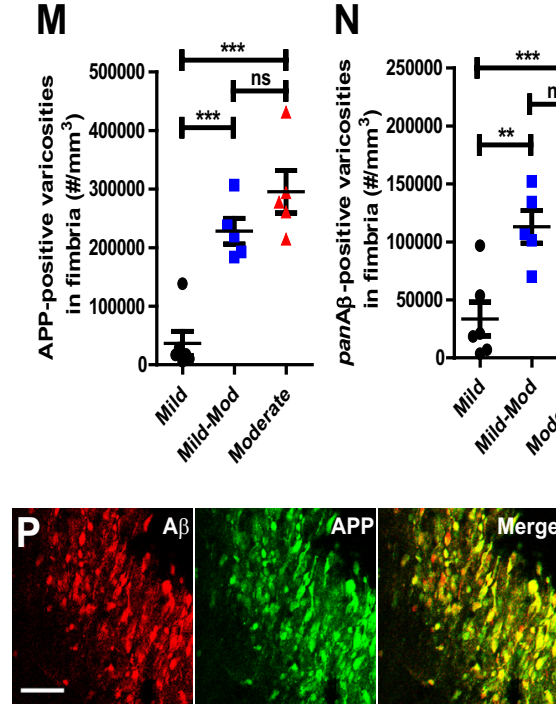

Mild TBI
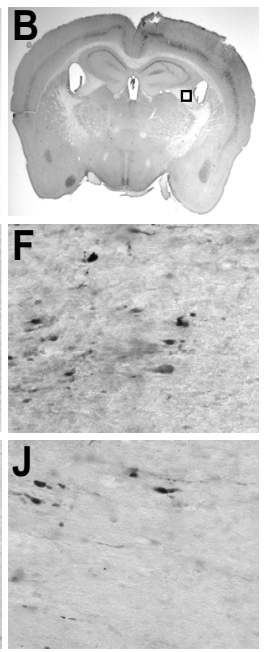

$\mathrm{N}$
Mild-Mod TBI
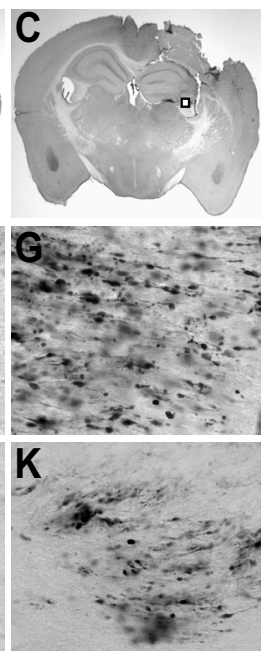

0

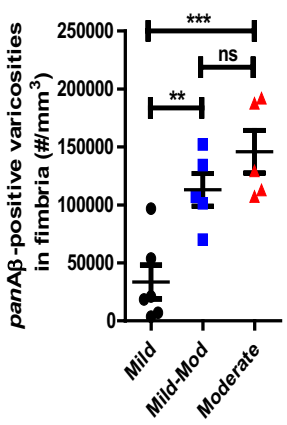

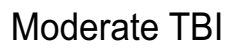
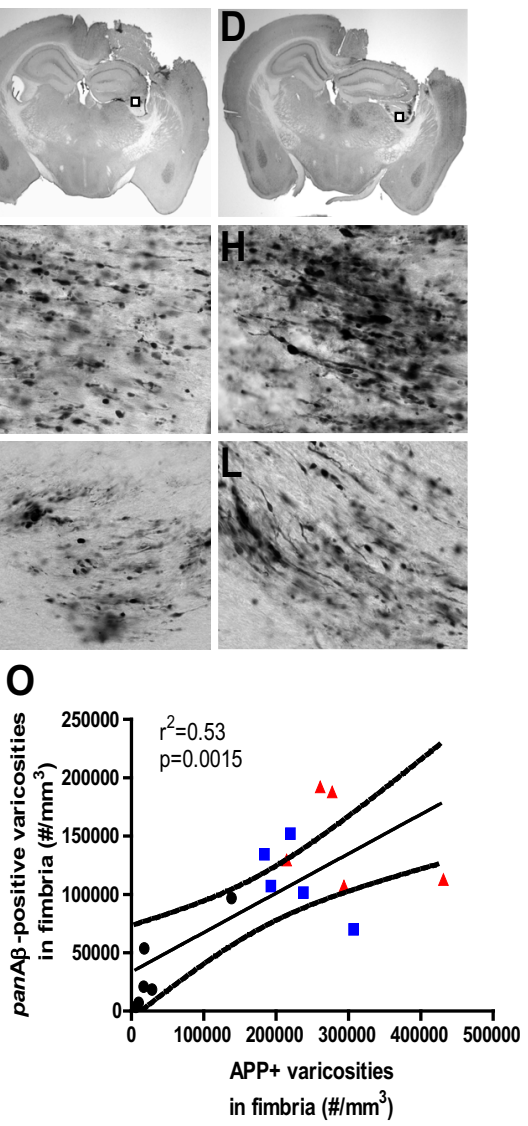

Figure 3. $A \beta$ accumulation varied with injury severity and colocalized with markers of axonal injury in $3 x T g-A D$ mice. $A-D, A P P$ immunohistochemistry (IHC) of sham, mildly $(1.0 \mathrm{~mm})$, mild-moderately $(1.5 \mathrm{~mm})$, and moderately $(2.0 \mathrm{~mm})$ injured, young 3xTg-AD mice. Scale bar, $2 \mathrm{~mm}$. $\boldsymbol{E}-\boldsymbol{H}$, Higher magnification of axonal injury detected by APP IHC in the ipsilateral fimbria $(\boldsymbol{A}-\boldsymbol{D}$, boxes). Scale bar, $50 \mu \mathrm{m}$. $\boldsymbol{I}-\boldsymbol{L}$, Intra-axonal $\mathrm{A} \beta \mathrm{IHC}$ in the ipsilateral fimbria using pan- $\mathrm{A} \beta$ antibody against $\mathrm{A} \boldsymbol{\beta}_{15-30} . \boldsymbol{M}$, Stereological quantification of numbers of APP-stained varicosities per cubic millimeter of the ipsilateral fimbria as a function of injury severity. $\boldsymbol{N}$, Stereological quantification of numbers of $A \beta$-stained varicosities per cubic millimeter of the ipsilateral fimbria as a function of injury severity. Error bars represent mean \pm SEM. ${ }^{* *} p<0.01 ;{ }^{* * *} p<0.005$, one-way ANOVA with Newman-Keuls post hoc test. ns, Not significant; Mild-Mod, mild-moderate. $\boldsymbol{O}$, Pearson's correlation of numbers of A $\beta$ - and APP-stained varicosities in injured fimbria; $r^{2}=0.53, p=0.0015 . n=5-6$ mice per injury severity. $P$, Colocalization of A $\beta$ with APP in injured fimbria of a 3xTg-AD mouse. Scale bar: $50 \mu \mathrm{m}$. Q , Colocalization of $A \beta$ with neurofilament light chain $68 \mathrm{kDa}$ (NF-L68), another marker of axonal injury, in injured fimbria of a $3 \times \mathrm{Tg}-\mathrm{AD}$ mouse. $A \beta$ was detected with monoclonal $3 \mathrm{D} 6$ antibody conjugated to Alexa Fluor 594 (red). This antibody requires a free N terminus of A $\beta$ for binding and does not cross-react with APP. APP and NF-L68 were visualized with a secondary antibody conjugated to Alexa 488 (green).

pocampi (Fig. $2 A, B$ ), a significant increase in insoluble total $\mathrm{A} \beta$ was detected in $5 \mathrm{M}$ guanidine ipsilateral hippocampal lysates of injured compared with sham $3 \times \mathrm{Tg}-\mathrm{AD}$ (Mann-Whitney $U$ test, $p=0.0047$ ) (Fig. 2C). There was a nonsignificant trend toward increased guanidine total $A \beta$ levels in the contralateral hippocampi of injured mice compared with sham (Fig. 2C). Furthermore, we found a significant increase in $A \beta_{1-40}$ and a trend toward increased $\mathrm{A} \beta_{1-42}$ in the ipsilateral hippocampal lysates of injured $3 \times \mathrm{Tg}$-AD mice (Fig. $2 D, E$ ). Overall, these data are concordant with the immunohistochemical evidence of intracellular $\mathrm{A} \beta$ accumulation after TBI in these mice.
Previous studies have found that more severe TBI results in more APP accumulation in damaged axons (Blumbergs et al., 1995; Bramlett et al., 1997). Since A $\beta$ is derived from proteolytic cleavage of APP and accumulates in axons of 3xTg-AD mice after TBI, we hypothesized there would be a correlation between axonal injury severity and extent of $A \beta$ accumulation in these mice. To test this hypothesis, we performed additional mild $(1.0 \mathrm{~mm}$ impact below dura) and mild-moderate ( $1.5 \mathrm{~mm}$ impact below dura) injuries on $3 \mathrm{xTg}-\mathrm{AD}$ mice. We compared $\mathrm{A} \beta$ - and APP-labeled axonal pathologies among the mild, mild-moderate, and moderate (2.0 $\mathrm{mm}$ ) TBI groups using immunohistochemistry and stereological quantification.

We found that both APP and A $\beta$ accumulations in pericontusional white matter were dependent on injury severity in young $3 x T g-A D$ mice. Specifically, few injured axons stained for APP were found in the ipsilateral fimbria/fornix of mildly injured 3xTg-AD mice $(1.0 \mathrm{~mm})$ (Fig. $3 B, F)$. Many more APP-stained axonal varicosities were observed in the same region in the other injured groups (1.5 and $2.0 \mathrm{~mm}$ ) (Fig. $3 C, D, G, H$ ), but none in the sham injured ones (Fig. $3 A, E$ ). Furthermore, we found a parallel relationship between the extent of the axonal injury and the amount of intra-axonal $A \beta$ in the fimbria/fornix (Fig. 3I-L). Markedly fewer $\mathrm{APP}$ - and $\mathrm{A} \beta$-stained varicosities were observed in other injured white matter regions such as the ipsilateral pericontusional hippocampal commissure, ipsilateral external capsule, and ipsilateral corpus callosum (data not shown). In these other regions, the extent of both APP and $\mathrm{A} \beta$ staining was similarly dependent on injury severity (data not shown).

To quantitatively characterize the observed relationship between injury severities and the extent of APP and A $\beta$ accumulations in injured axons of the fimbria/fornix, we used the optical fractionator stereological method. We found significantly more APP-stained varicosities in the mildmoderate and moderate TBI groups compared with the mild TBI group (Fig. $3 M$ ) (one-way ANOVA, $p<0.0001$ ). There was a trend toward an increasing number of APP-stained varicosities in the moderate TBI group $(2.0$ $\mathrm{mm}$ ) compared with the mild-moderate TBI group $(1.5 \mathrm{~mm})$, but this was not statistically significant (Fig. $3 M$ ). A similar relationship between injury severities and numbers of $\mathrm{A} \beta$-stained varicosities was observed: the more severe the injury, the more intra-axonal $\mathrm{A} \beta$ accumulation (Fig. $3 N$ ) (one-way ANOVA, $p=0.0005$ ). There was a statistically significant positive correlation between the numbers of APP- and $\mathrm{A} \beta$-stained varicosities (Fig. 3O) (Pearson $r^{2}=0.53, p=0.0015$ ).

To determine definitively whether these accumulations of $A \beta$ were found within injured axons, we performed double-immuno- 
fluorescence labeling of A $\beta$ and APP and separate double immunofluorescence with the $68 \mathrm{kDa}$ neurofilament light chain subunit, NF-L68. APP and NF-L68 are well established axonal markers, and accumulations of both proteins are robust signatures of axonal injury (Gennarelli et al., 1982; Yaghmai and Povlishock, 1992; Gentleman et al., 1993; Grady et al., 1993; Christman et al., 1994; Sherriff et al., 1994; Graham et al., 1995; Povlishock and Christman, 1995; Chen et al., 1999; Smith et al., 1999; Stone et al., 2000, 2001; Marmarou et al., 2005). They have been shown to extensively colocalize with $\mathrm{A} \beta$ in injured axons from human TBI patients (D. H. Smith et al., 2003; Uryu et al., 2007; Chen et al., 2009). We found that essentially all $\mathrm{A} \beta$-immunoreactive axonal varicosities in injured $3 \mathrm{xTg}-\mathrm{AD}$ mice were also positive for APP and NF-L68 on confocal microscopy (Fig. $3 P, Q$ ). A $\beta$ labeling was performed using the monoclonal anti-A $\beta$ antibody 3D6 directly conjugated to Alexa Fluor 594; 3 D6 does not cross-react with APP as it requires a free $\mathrm{N}$ terminus to bind (Johnson-Wood et al., 1997). No such colocalization was observed in sham 3xTg-AD mice (data not shown), nor when one of the primary antibodies was omitted (data not shown). Thus, controlled cortical impact TBI in 3xTg-AD mice reproduced one of the hallmark features of human post-TBI neurodegenerative pathology: intra-axonal $A \beta$ accumulation at sites of traumatic axonal injury.

To summarize, intra-axonal $\mathrm{A} \beta$ accumulation appeared consistently in 3xTg-AD mice after experimental TBI. This intraaxonal $\mathrm{A} \beta$ appeared to be in a relatively insoluble form. Moreover, $A \beta$ colocalized with markers of axonal injury and correlated with severity of axonal injury.

\section{Increased total tau and phospho-tau immunoreactivity after TBI in 3xTg-AD mice}

We next investigated the effects of TBI on tau accumulation and phosphorylation in the same injured and sham $3 x \mathrm{Tg}-\mathrm{AD}$ mice.

We first performed immunohistochemistry using polyclonal tau antibody (pAb Tau) and monoclonal HT7, which recognize both normal and hyperphosphorylated human tau. Negative controls included injured wild-type mice and omission of primary antibodies. Brain slices from 12-month-old 3xTg-AD mice served as a positive control.

In the pericontusional fimbria/fornix, abnormal punctate tau immunoreactivity was observed after moderate TBI in 3xTg-AD mice (Fig. $4 A, D$ ). There was minimal tau staining in the same region of sham injured mice (Fig. $4 B, E$ ) and none in moderately injured wild-type mice (Fig. 4C,F). Interestingly, there were two additional regions in which there were marked increases in tau immunoreactivity in injured compared with sham $3 x T g-A D$ mice. These were the ipsilateral amygdala and contralateral CA1 regions (Fig.
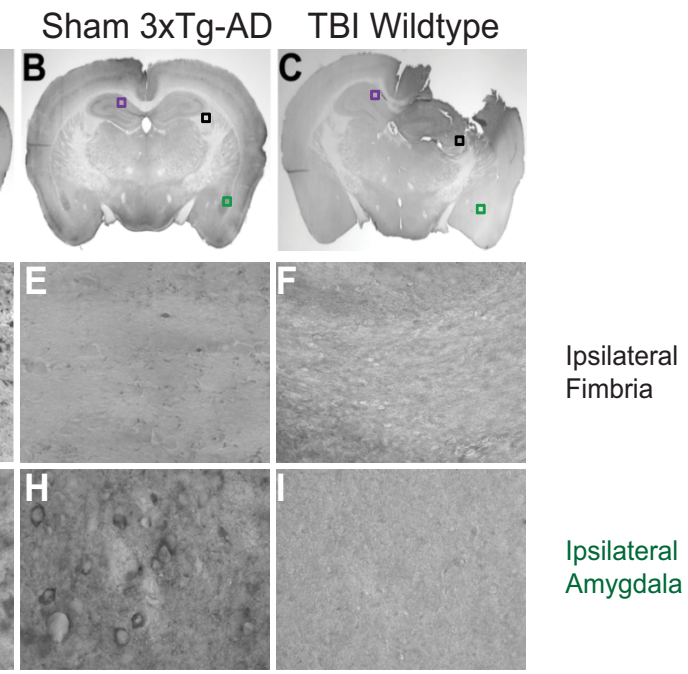

Ipsilateral

Amygdala
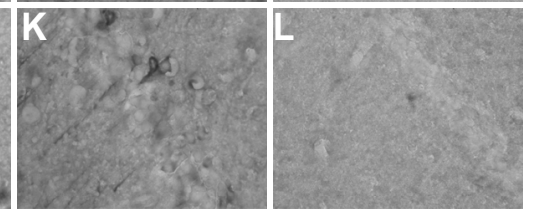

Contralateral

CA1

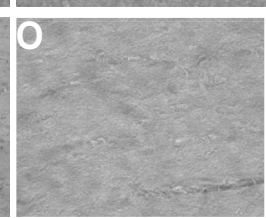

Ipsilateral

Fimbria

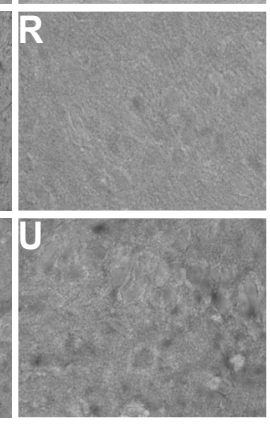

Ipsilateral

Amygdala
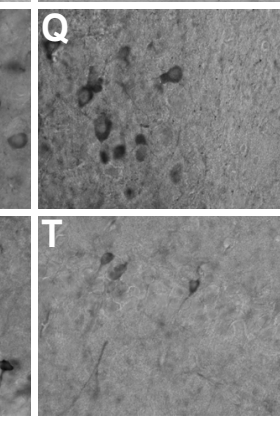

Contralateral

CA1

Figure 4. Controlled cortical impact TBI accelerated tau pathology in young 3xTg-AD mice. Total tau (independent of phosin injured 3xTg-AD mice, sham 3xTg-AD mice, and injured wild-type mice, respectively. $D-F$, Higher magnification of the ipsilateral fimbria ( $\boldsymbol{A}-\boldsymbol{C}$, black boxes). $\mathbf{G}-\boldsymbol{I}$, Higher magnification of the ipsilateral amygdala ( $\boldsymbol{A}-\boldsymbol{C}$, green boxes). $\boldsymbol{J}-\boldsymbol{L}$, Higher magnifi-

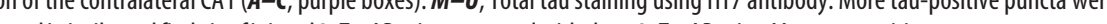
sserved in ipsilateral fimbria of injured 3xTg-AD mice compared with sham 3xTg-AD mice. More tau-positive somata were presen in ipsilateral amygdala of injured compared with sham 3xTg-AD mice. More tau-positive processes were also observed in the contralateral CA1 of injured compared with sham 3xTg-AD mice. No tau immunoreactivity was observed in injured wild-type mice.

$4 A, B, G, H, J, K)$. Tau immunoreactivity in the amygdala had a perinuclear cytoplasmic distribution, whereas that in the contralateral CA1 took the appearance of elongated neurites. These regions are distant from the site of injury but are anatomically connected to the ipsilateral hippocampus via the ipsilateral fimbria/fornix tract (Witter and Amaral, 2004). Similar patterns of tau staining were observed in injured and sham 3xTg-AD mice when monoclonal HT7 against total tau was used (Fig. 4M, N$, P, Q, S, T)$. No total tau immunoreactivity was observed in injured wild-type mice (Fig. $4 C, F, I, L, O, R, U$ ). Total tau immunoreactivity in the ipsilateral hippocampus was not significantly affected by TBI in these mice (data not shown).

Next, we examined the effects of varying injury severity on total tau pathology in $3 \times \mathrm{Tg}-\mathrm{AD}$ mice (Fig. $5 B-D$ ). Abnormal 

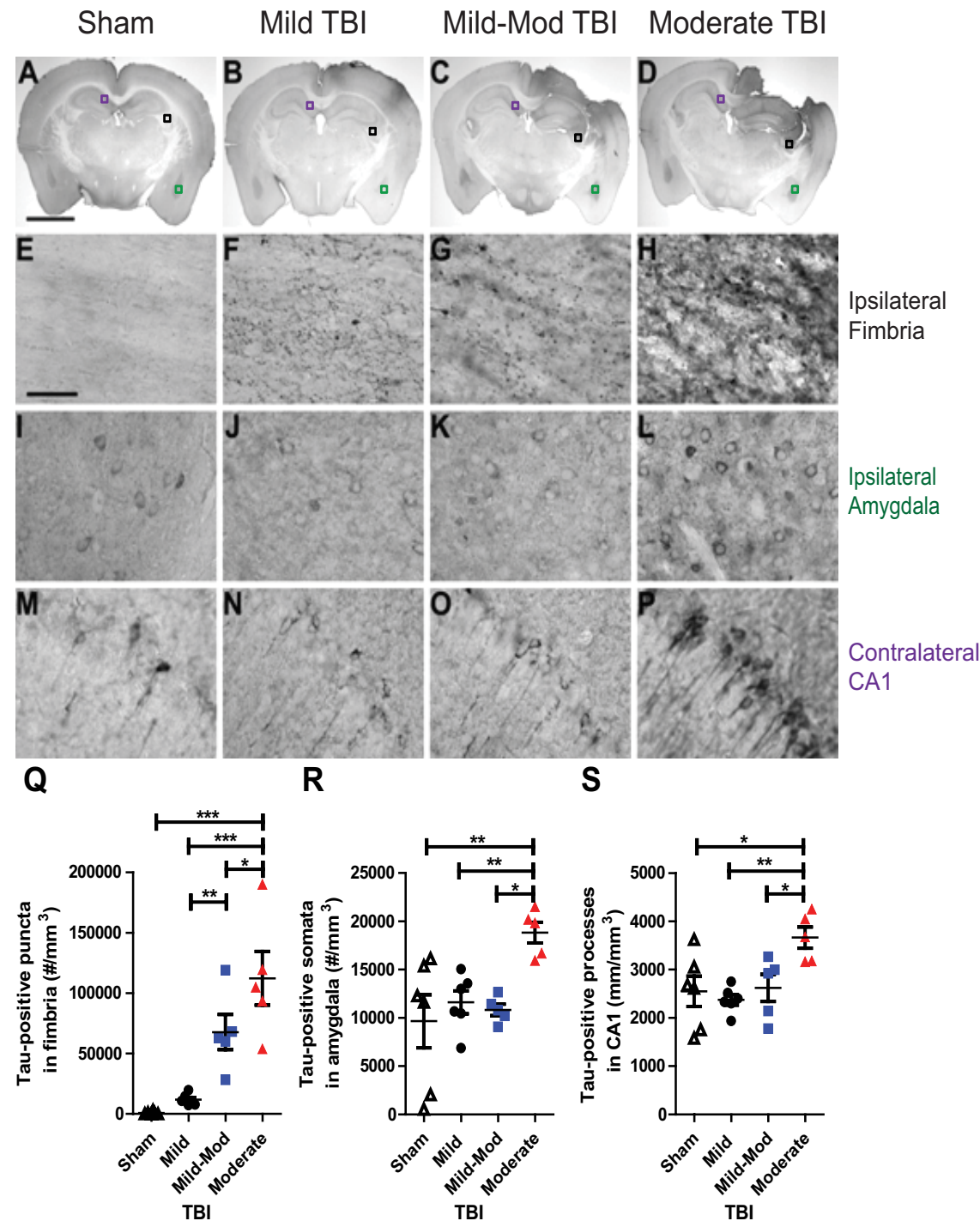

Figure 5. Tau pathology varied with injury severity in young 3xTg-AD mice. A-D, pAb Tau immunohistochemistry of sham, mildly $(1.0 \mathrm{~mm})$, mild-moderately $(1.5 \mathrm{~mm})$, and moderately $(2.0 \mathrm{~mm})$ injured, young $3 \mathrm{xTg}$-AD mice. Scale bar, $2 \mathrm{~mm}$. $\boldsymbol{E}-\boldsymbol{H}$, Higher magnification of tau staining in the ipsilateral fimbria $(\boldsymbol{A}-\boldsymbol{D}$, black boxes). Scale bar, $50 \mu \mathrm{m}$. $\boldsymbol{I}-\boldsymbol{L}$, Higher magnification of tau staining in the ipsilateral amygdala $(\boldsymbol{A}-\boldsymbol{D}$, green boxes). $\boldsymbol{M}-\boldsymbol{P}$, Higher magnification of tau staining in the contralateral CA1 ( $\boldsymbol{A}-\boldsymbol{D}$, purple boxes). $\boldsymbol{Q}$, Stereological quantification of numbers of tau-stained punctate varicosities per cubic millimeter of the ipsilateral fimbria as a function of injury severity. $\boldsymbol{R}$, Stereological quantification of numbers of tau-stained somata per cubic millimeter of the ipsilateral amygdala as a function of injury severity. $\boldsymbol{S}$, Stereological quantification of tau-immunoreactive neuritic processes per cubic millimeter of the contralateral CA1 as a function of injury severity. $n=5-6$ mice per injury severity. Error bars represent mean $\pm S E M$. ${ }^{*} p<0.05$; ${ }^{* *} p<0.01 ;{ }^{* * *} p<0.005$, one-way ANOVA with Newman-Keuls post hoc test. Mild-Mod, mild-moderate.

tau-positive puncta in the ipsilateral fimbria appeared to increase in an injury-severity-dependent manner (Fig. $5 F-H$ ). There was minimal tau staining in the same region of sham injured mice (Fig. 5A,E). Only in the moderate TBI group were there more tau-positive somata in the ipsilateral amygdala and tau-positive neurites in the contralateral CA1 (Fig. 5I-P). No tau immunoreactivity was observed in injured $3 \mathrm{xTg}-\mathrm{AD}$ mice when the primary antibody was omitted (data not shown).

Quantitative analyses of tau immunoreactivity in these regions using stereology confirmed the qualitative histological findings. There were significantly more tau-positive puncta in ipsilateral fimbria/fornix as the injury became more severe (Fig. 5Q) (one-way ANOVA, $p<0.0001)$. In the moderately injured group $(2.0 \mathrm{~mm})$, there was a significant increase in tau-positive somata in the ipsilat- eral amygdala compared with other TBI and sham groups (Fig. $5 R$ ) (one-way ANOVA, $p=0.008$ ). Likewise, tau-positive neurite length density in the contralateral CA1 of these moderately injured mice was significantly greater than the length density in the other groups (Fig. 5S) (one-way ANOVA, $p=0.0079)$.

To test whether TBI increased the extent of tau phosphorylation in $3 \mathrm{xTg}-\mathrm{AD}$ mice, we performed additional immunohistochemical studies using polyclonal antibodies against phosphorylated tau in sham and moderately injured mice. Injured mice exhibited more phospho-tau staining than sham mice for all the phospho-tau antibodies used. Specifically, phospho-S199 tau was observed in ipsilateral hippocampal CA1 and fimbria of moderately injured mice (Fig. 6A,C). Immunoreactivity for phospho-T205 was prominent in ipsilateral fimbria only (Fig. $6 E$ ). Tau also appeared to be heavily phosphorylated at T231, S396, and S422 in fimbria of $3 \mathrm{xTg}-\mathrm{AD}$ mice after TBI (Fig. $6 G, I, K)$. No phospho-tau immunoreactivity was observed in sham $3 \mathrm{xTg}$-AD mice at 6 months of age (Fig. $6 B, D, F, H, J, L$ ).

To further confirm these findings, separate groups of sham and moderately injured mice were killed at $24 \mathrm{~h}$ by rapid decapitation. Bilateral hippocampi were quickly removed and frozen. Tissue was homogenized in RIPA buffer and subjected to Western blotting using the monoclonal AT8 antibody against phosphorylated tau at S199 or S202 and T205, the AT100 antibody against phosphorylated tau at T212 and S214, and the AT180 antibody against phosphorylated tau at T231 (Mercken et al., 1992). Blots were stripped and reprobed with the Tau46 antibody to quantify total tau.

We found marked increases in the densities of AT8-, AT100-, and AT180immunoreactive bands in injured compared with sham $3 \mathrm{xTg}-\mathrm{AD}$ mice, indicating an increase in levels of tau phosphorylation (Fig. 6M-O). Total tau levels in these samples appeared slightly lower in the injured mice (Fig. $6 \mathrm{M}$ ). Overall, there were approximately twofold increases in the ratio of AT8-, AT100-, and AT180-immunoreactive phospho-tau band densities to total tau band densities after TBI in 3xTg-AD mice (Fig. 6M-O) (Mann-Whitney $U$ test, $p<0.05$ ). No such immunoreactivity for tau was observed when primary antibody was omitted (data not shown). No increases in tau phosphorylation were detected in contralateral hippocampal lysates (data not shown).

In summary, experimental TBI caused increased tau immunoreactivity in 6-month-old 3xTg-AD mice. Notably, the spatial distribution of TBI-related changes in tau immunoreactivity was distinct from those of postinjury $A \beta$. Levels of tau phosphorylation were significantly increased after TBI, based on both biochemical and immunohistochemical analyses. 
Effects of $\boldsymbol{\gamma}$-secretase inhibition on posttraumatic $A \boldsymbol{\beta}$ accumulation and tau pathologies

The findings that both $\mathrm{A} \beta$ and tau pathologies were accelerated by controlled cortical impact allowed us the opportunity to investigate the interaction between $\mathrm{A} \beta$ and tau in the setting of TBI.

To investigate the interaction between $\mathrm{A} \beta$ and tau pathologies, we blocked $\mathrm{A} \beta$ production using a $\gamma$-secretase inhibitor. $\gamma$-Secretase is one of the canonical enzymes required for proteolytic processing of APP to form $A \beta$ (Selkoe, 2001). If tau is downstream of $A \beta$ in the setting of TBI, we expected to see amelioration of tau abnormalities after blocking $\mathrm{A} \beta$ production. However, if tau and $\mathrm{A} \beta$ are independently affected by trauma, blocking $A \beta$ production should have no effects on tau pathology observed after TBI in these mice.

We first confirmed that inhibition of $\gamma$-secretase blocked intra-axonal $A \beta$ buildup in 3xTg-AD mice after moderate TBI. We treated injured mice with $\mathrm{CmpE}$, a smallmolecule inhibitor of $\gamma$-secretase (Seiffert et al., 2000; Olson et al., 2001; Grimwood et al., 2005; Yang et al., 2008; Yan et al., 2009) or DMSO vehicle. Mice received intraperitoneal injections of $10 \mathrm{mg} / \mathrm{kg}$ $\mathrm{CmpE}$ or vehicle at $1 \mathrm{~h}$ before injury and then again at 5, 11, and $17 \mathrm{~h}$ after injury. The frequent dosing regimen was used because of the short half-life of CmpE (Yan et al., 2009). A relatively high dose was used as a result of the presence of a PS1 mutation in $3 \times \mathrm{Tg}-\mathrm{AD}$ mice, since such mutations may result in diminished response to $\gamma$-secretase inhibition (Czirr et al., 2007). In our first experiment, mice were killed at $24 \mathrm{~h}$ after injury. One group of CmpE- and vehicle-treated mice was used for immunohistochemical analysis, and another group was used for biochemical assessment. For histology, we used polyclonal antibody $\mathrm{A} \beta_{40}$ for $\mathrm{A} \beta$ immunohistochemistry in this experiment since $\gamma$-secretase cleavage of APP is at the $\mathrm{C}$ terminus of $\mathrm{A} \beta$; N-terminal anti-A $\beta$ antibodies would still recognize the longer APP fragments remaining after $\gamma$-secretase inhibition. We stained these brains for APP to assess the extent of axonal injury. We also assessed full-length $\alpha$-CTFs and $\beta$-CTFs (APP fragments resulted from cleavage of APP by $\alpha$ - and $\beta$-secretases, respectively) in the cerebellar lysates of the same mice via Western blot to demonstrate that $\mathrm{CmpE}$ was effective at inhibiting brain $\gamma$-secretase activity. For the biochemical assessment, we killed mice by rapid decapitation and homogenized ipsilateral hippocampi in RIPA buffers. RIPA lysates of CmpE- and vehicle-treated mice were used to determine levels of $\mathrm{A} \beta_{40}$ by ELISA.

$\mathrm{CmpE}$ treatment almost completely prevented intra-axonal $\mathrm{A} \beta$ accumulation in ipsilateral fimbria of injured $3 \mathrm{xTg}-\mathrm{AD}$ mice (Fig. $7 A, B$ ). Stereological quantification of numbers of $\mathrm{A} \beta_{40^{-}}$ positive axonal varicosities showed $\sim 90 \%$ reduction in CmpEversus vehicle-treated mice (Fig. 7E) (one-sided $t$ test, $p<$
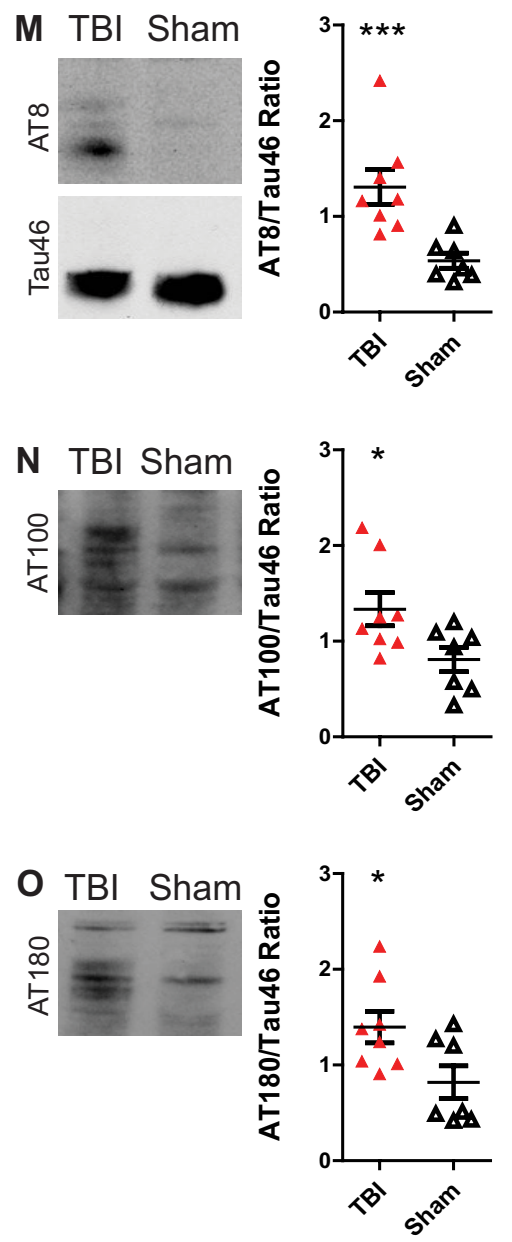
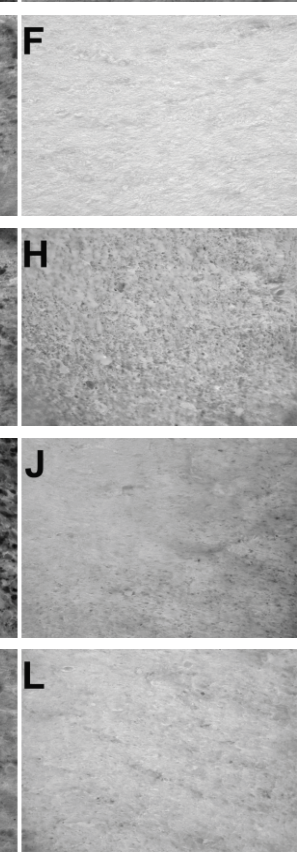

Figure 6. Controlled cortical impact TBl increased levels of phospho-tau immunoreactivity in ipsilateral hippocampi and fimbria phosphorylated tau at $\mathbf{S 1 9 9}$. Scale bar, $50 \mu \mathrm{m}$. A, B, Ipsilateral hippocampal CA1. C, D, Ipsilateral fimbria. E-L, Phospho-tau staining in fimbria of TBI and sham 3xTg-AD mice using polyclonal antibodies against tau phosphorylated at T205 (E, $\boldsymbol{F})$, T231 ( $G$ mice. AT8 blots were stripped and reprobed with Tau46 antibody for total tau. A significant increase in ratio of AT8 to Tau 46 band densities was observed after TBI ( ${ }^{* * *} p=0.0006$, Mann-Whitney $U$ test). $\boldsymbol{N}$, Representative AT100 Western blot of ipsilatera abserved after TBI ( ${ }^{*} p=0.03$, Student's $t$ test). $\boldsymbol{O}$, Representative AT180 Western blot of ipsilateral hippocampi from $2.0 \mathrm{~mm}$ TB and sham 3xTg-AD mice. A significant increase in ratio of AT180 to Tau46 band densities was observed after TBI ${ }^{*} p=0.03$, Student's $t$ test). $n=7-8$ mice per group. Error bars represent mean \pm SEM.

0.0001). Biochemical quantification of RIPA-soluble $\mathrm{A} \beta_{40}$ in ipsilateral hippocampi and surrounding white matter showed similar reduction (CmpE-treated mice, $32.5 \pm 2.87 \mathrm{pg} / \mathrm{mg}$ vs vehicle-treated mice, $217.9 \pm 52.1 \mathrm{pg} / \mathrm{mg}$; one-sided $t$ test, $p=$ $0.0013)$. CmpE effectively blocked $\gamma$-secretase activity in the setting of TBI, as evidenced by similar levels of full-length APP but increased $\alpha$-CTFs and $\beta$-CTFs in cerebellar lysates of mice with CmpE treatment (data not shown). Furthermore, numbers of APP-stained varicosities were similar between treatment groups (Fig. $7 F, G, J$ ). This finding demonstrated that $\gamma$-secretase inhibition by CmpE specifically reduced proteolytic $\mathrm{A} \beta$ production, rather than reducing $A \beta$ pathology by affecting extent of axonal injury in these injured mice.

CmpE treatment had no effect on tau pathologies in 3xTg-AD mice killed at $24 \mathrm{~h}$ after TBI, despite the $90 \%$ reduction in $\mathrm{A} \beta$ accumulation (Fig. 8). We assessed total and phosphorylated tau 

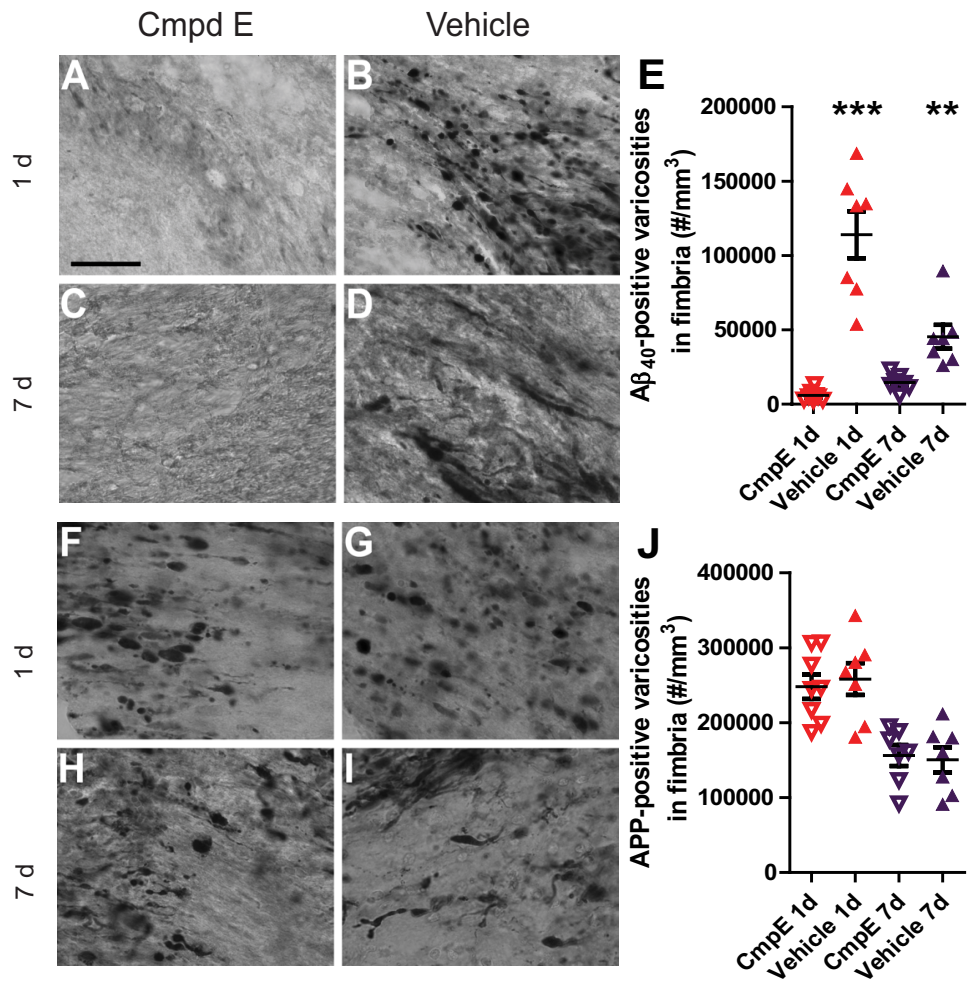

Figure 7. Systemic inhibition of $\gamma$-secretase activity with $C \mathrm{mpE}$ blocked posttraumatic $A \beta$ accumulation at 1 and $7 \mathrm{~d}$ after injury but did not alter the extent of axonal injury. $A, B, A \beta_{40}$ immunohistochemistry (IHC) for injured $3 \times T g-A D$ mice receiving CmpE or vehicle (DMSO) treatment killed at $24 \mathrm{~h}$ after injury. $C, D, A \beta_{40} I H C$ for injured $3 x T g-A D$ mouse receiving $C \mathrm{CmpE}$ or vehicle treatment for $7 \mathrm{~d}$ after injury. $E$, Stereological quantification of numbers of $A \beta_{40}$-stained varicosities in the ipsilateral fimbria of injured 3xTg-AD mice receiving either $\mathrm{CmpE}$ or vehicle treatment at 1 and $7 \mathrm{~d}$ after TBI. These data demonstrated intra-axonal $A \beta$ buildup after TBI could be inhibited by blocking $\gamma$-secretase activity. ${ }^{* * *} p<0.0001$; ${ }^{* *} p=0.0015$, Student's test. F, G, APP IHC of fimbria from injured 3xTg-AD mice treated with CmpE or vehicle killed at $24 \mathrm{~h}$ after injury. $H, I, A P P$ IHC of fimbria from injured 3xTg-AD mice treated with CmpE or vehicle for $7 \mathrm{~d}$ after injury.J, Stereological quantification of APP-positive axonal varicosities in ipsilateral fimbria of injured mice treated with CmpE or vehicle killed at 1 and $7 \mathrm{~d}$ after TBI. Similar numbers of APP-positive axonal varicosities in the two treatment groups indicate $\mathrm{CmpE}$ treatment did not affect the extent of axonal injury in these mice. $n=7-8$ mice per group. Error bars represent mean \pm SEM.

levels in injured 3xTg-AD mice treated with $\mathrm{CmpE}$ or vehicle. Specifically, we studied tau pathology histologically with polyclonal total tau antibody, phospho-S199 antibody against tau phosphorylated at S199, and PHF1 antibody against phosphorylated tau at S396 and S404. We also examined tau pathology biochemically via Western blots using the AT8, AT100, and Tau46 antibodies. Finally, we investigated total and phospho-S199 levels by ELISA. All assessments were done in a blinded fashion.

Using quantitative stereological methods as described above, we found that the numbers of total tau-positive puncta in the ipsilateral fimbria, the numbers of total tau-stained somata in the ipsilateral amygdala, and total length density of tau-positive CA1 processes were not affected by $\mathrm{CmpE}$ treatment in injured $3 x$ Tg-AD mice (Fig. 8A, B,E-G,J-L,O). Total tau levels in the ipsilateral hippocampal tissues of injured mice treated with $\mathrm{CmpE}$ were not statistically different from those of vehicle-treated mice, as assessed by human tau ELISA (CmpE-treated mice, $819.7 \pm 99.38$ $\mathrm{pg} / \mathrm{mg}$ vs vehicle-treated mice, $796.6 \pm 161.1 \mathrm{pg} / \mathrm{mg}$; Student's $t$ test, $p=0.9)$.

The increases in tau phosphorylation after TBI were not affected by $\mathrm{CmpE}$ treatment. There were similar numbers of pS199- and PHF1-positive tau puncta in ipsilateral fimbria of injured mice treated with CmpE compared with vehicle-treated mice (Fig. 8P, Q, $T, U, V, Y)$. Phospho-tau $S 199$ levels in ipsilateral hippocampi assessed by ELISA revealed similar levels in CmpE- and vehicle-treated mice (CmpE group, $61.1 \pm 9.2 \mathrm{pg} / \mathrm{mg}$ vs vehicle group, $57.9 \pm 13.9 \mathrm{pg} / \mathrm{mg}$; Student's $t$ test, $p=0.85)$. Ipsilateral hippocampi of CmpE- and vehicle-treated mice subjected to Western blotting using AT8 and AT100 antibodies also corroborated these findings (AT8/Tau 46 ratio for CmpE group, $1.01 \pm$ 0.04 vs vehicle group, $1.09 \pm 0.07$; AT100/ Tau46 ratio for CmpE group, $1.01 \pm 0.03$ vs vehicle group, $1.08 \pm 0.05$ ). Tau pathologies in these experimental groups were qualitatively and quantitatively similar to those seen in the moderately injured mice that received neither vehicle nor $\mathrm{CmpE}$ (Figs. $4-6)$. Thus, it was unlikely that there were any effects of DMSO vehicle treatment or the additional handling required for the injections.

Furthermore, we examined the effects of $\mathrm{CmpE}$ or vehicle treatment on injured mice up to $7 \mathrm{~d}$ after TBI. We chose this survival period because we found that both $\mathrm{A} \beta$ and tau abnormalities persisted in untreated, injured mice at $7 \mathrm{~d}$ after TBI, although to a lesser extent than those observed at $24 \mathrm{~h}$ after TBI. Mice received $\mathrm{CmpE}$ or vehicle injections four times in the first $24 \mathrm{~h}$ as described above and then twice daily until they were killed at $7 \mathrm{~d}$ after injury. We stained brain sections for $\mathrm{A} \beta_{40}$, APP, total tau, phospho-S199, and PHF1 to assess the effects of CmpE treatment on both $\mathrm{A} \beta$ and tau abnormalities.

Extended $\mathrm{CmpE}$ treatment successfully blocked the accumulation of the $\mathrm{A} \beta$ in the ipsilateral fimbria/fornix of injured $3 \times \mathrm{Tg}-\mathrm{AD}$ mice at $7 \mathrm{~d}$ (Fig. 7C-E) (onesided $t$ test, $p=0.001)$. In vehicle-treated mice, there were still numerous A $\beta$-positive (Fig. $7 D$ ) and APPpositive (Fig. 7I) varicosities at $7 \mathrm{~d}$, although the extent of staining was reduced compared with $24 \mathrm{~h}$ after TBI (Fig. $7 E, J$ ). Similar to the acute $\mathrm{CmpE}$ treatment experiments, extended $\mathrm{CmpE}$ treatment did not alter the extent of axonal injury as assessed by numbers of APP-positive varicosities in the ipsilateral fimbria/ fornix (Fig. 7H-J). Furthermore, total tau immunoreactivity in the fimbria, amygdala, and CA1 were not statistically different in CmpE- and vehicle-treated mice (Fig. $8 C-E, H-J, M-O$ ). Importantly, tau phosphorylation at phospho-S199 and PHF1 epitopes was also unaffected after $7 \mathrm{~d}$ of CmpE treatment (Fig. $8 R-T, W-Y$ ). Thus, we did not observe a delayed effect of inhibition of $A \beta$ accumulation on tau pathology after TBI.

In summary, inhibition of $\gamma$-secretase activity with $\mathrm{CmpE}$ successfully blocked posttraumatic $\mathrm{A} \beta$ generation and buildup in injured axons in 3xTg-AD mice but did not affect either local or distant tau immunoreactivity. This provides experimental evidence that posttraumatic acceleration of $\mathrm{A} \beta$ and tau pathologies occur independently in this animal model.

\section{Discussion}

In summary, controlled cortical impact TBI in 3xTg-AD mice recapitulated two key pathological features observed in human TBI patients. First, rapid intra-axonal A $\beta$ accumulation was consistently detected in an area of axonal injury, the pericontusional 


\section{Cmp E Vehicle}
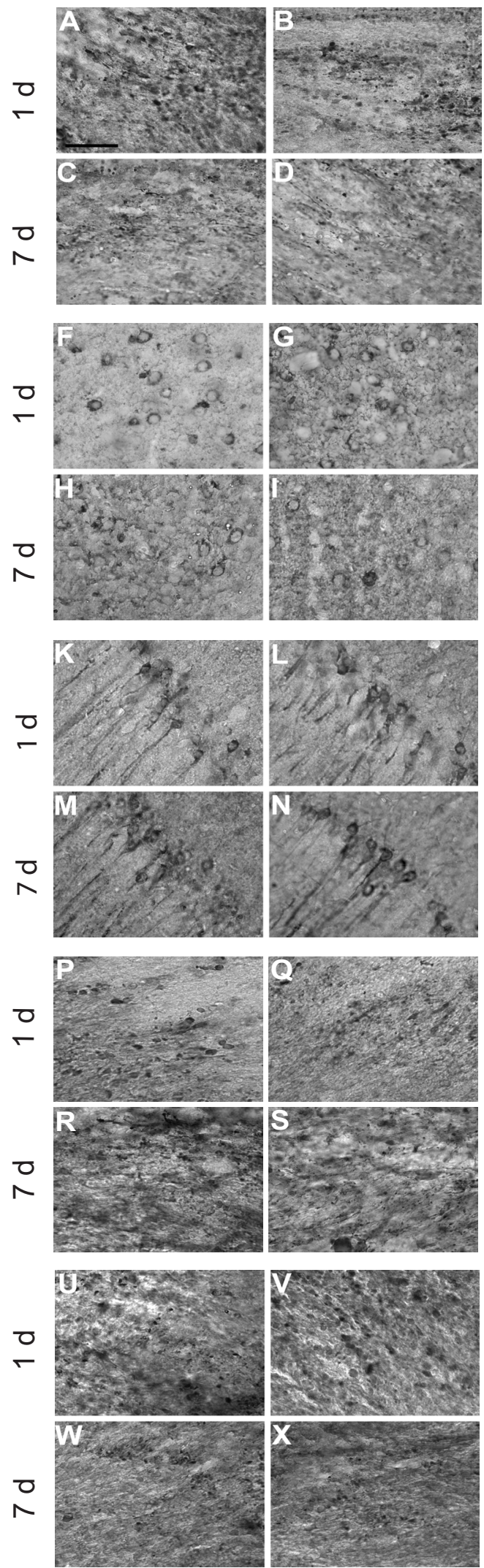
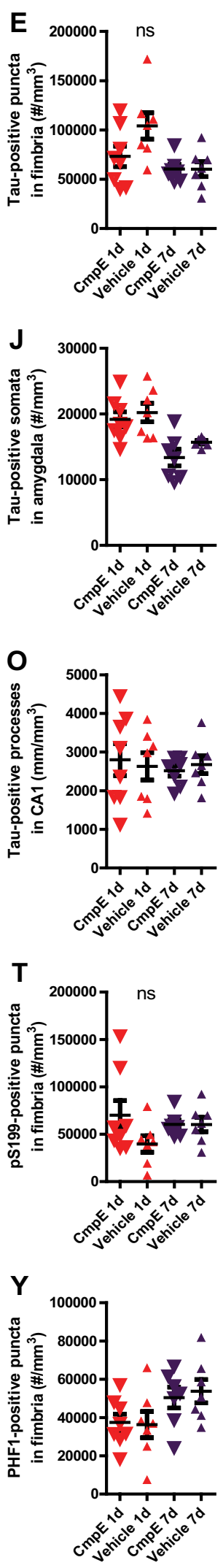

Figure 8. Inhibition of posttraumatic $A \beta$ formation by $\mathrm{CmpE}$ did not affect tau pathology after moderate $(2.0 \mathrm{~mm}) \mathrm{TB}$ in young $3 \times \operatorname{Tg}-A D$ mice. $\boldsymbol{A}-\boldsymbol{N}$, Total tau immunohistochemistry $(\mathrm{IHC})$ in the ipsilateral fimbria $(\boldsymbol{A}-\boldsymbol{D})$, ipsilateral amygdala $(\boldsymbol{F}-\boldsymbol{I})$, and contralateral CA1 $(\boldsymbol{K}-\boldsymbol{N})$ of mice treated with $\mathrm{CmpE}$ or vehicle killed at 1 or $7 \mathrm{~d}$ after injury. Stereological quantification of total tau-stained puncta in ipsilateral fimbria $(\boldsymbol{E})$, total tau-stained somata in ipsilateral amygdala $(\boldsymbol{J})$, and total tau-stained neurite

fimbria. This is similar to the intra-axonal $\mathrm{A} \beta$ accumulation observed in human TBI patients (D. H. Smith et al., 2003; Ikonomovic et al., 2004; Uryu et al., 2007; Chen et al., 2009). No such accumulation is expected at this age, and none was seen in sham-injured mice. Second, increased tau immunoreactivity was found in three distinct brain regions of moderately injured 3xTg-AD mice. There was immunohistochemical and biochemical evidence for increased tau accumulation and phosphorylation induced by TBI at several epitopes.

Axonal injury appears necessary for posttraumatic $\mathrm{A} \beta$ accumulation in this model, as the extent of intra-axonal $A \beta$ accumulation correlated well with injury severity and no $\mathrm{A} \beta$ was detected immunohistochemically in areas without axonal injury. $\mathrm{A} \beta$ was found colocalized with the axonal injury markers APP and NFL-68 in injured 3xTg-AD mice. Histological findings of $\mathrm{A} \beta$ accumulation after TBI were further confirmed biochemically; there was approximately twice the amount of insoluble total $\mathrm{A} \beta$ and $\mathrm{A} \beta_{40}$ in ipsilateral hippocampal tissues of moderately injured compared with uninjured mice. The significant increase in only $\mathrm{A} \beta_{40}$ levels after TBI in these mice may be related to the lack of extracellular $A \beta$ plaques observed by immunohistochemistry.

In addition to focal injuries, the controlled cortical impact TBI model used in this study also affected distant regions such as the contralateral hippocampi and ipsilateral amygdala. Evidence for this observation included a significant increase in total tau accumulation in the contralateral CA1 and ipsilateral amygdala of moderately injured mice. Interestingly, there was not a substantial increase in total tau accumulation in the ipsilateral hippocampus. Neuronal loss or injury may have caused release of tau into the extracellular space where it could not be detected by immunohistochemistry.

The subacute effects of TBI are evidenced in the persistent immunoreactiv-

\footnotetext{
length density in contralateral $\mathrm{CA} 1(\mathbf{0})$ of injured mice treated with $\mathrm{CmpE}$ or vehicle at 1 and $7 \mathrm{~d}$ post TBI is shown. $\boldsymbol{P}$-S, Phospho-tau IHC using pS199 antibody. I, Stereological quantification of pS199-positive puncta in ipsilateral fimbria of mice treated with $\mathrm{CmpE}$ or vehicle. $\boldsymbol{U}-\boldsymbol{X}$, Phospho-tau IHC using PHF1 antibody. $Y$, Stereological quantification of PHF1positive tau puncta in ipsilateral fimbria of injured mice treated with CmpE or vehicle. All measures of tau immunoreactivity were not statistically different between $\mathrm{CmpE}$ - and vehicle-treated mice (Mann-Whitney $U$ tests). $n=7-8$ mice per group. Error bars represent mean \pm SEM.
} 
ity of APP, $A \beta$, total tau, and phospho-tau in injured 3xTg-AD mice killed at $7 \mathrm{~d}$ after injury. However, there was less APP, $A \beta$, and total tau immunoreactivity at $7 \mathrm{~d}$ compared with $24 \mathrm{~h}$ after TBI, presumably because of progressive cell death and tissue loss at the affected regions at the later time point. Interestingly, tau phosphorylation at phospho-S199 and PHF1 epitopes remained elevated at $7 \mathrm{~d}$ after injury. This suggests a possible role for pathological tau on longer-term outcomes after TBI in vivo.

Importantly, inhibition of enzymatic activity of $\gamma$-secretase, one of the canonical enzymes involved in cleaving APP to form $\mathrm{A} \beta$ under physiological conditions, almost completely eliminated posttraumatic $\mathrm{A} \beta$ aggregation in injured $3 \mathrm{xTg}-\mathrm{AD}$. However, accelerated tau abnormalities observed after trauma in these mice appear likely to be independent of $A \beta$, since inhibition of intra-axonal $\mathrm{A} \beta$ buildup did not alter tau pathology. These findings were consistent during the acute $(24 \mathrm{~h})$ as well as the subacute $(7 \mathrm{~d})$ periods after TBI. This demonstrates the utility of this controlled cortical impact 3xTg-AD model in the mechanistic investigation of the association between TBI and ADrelated pathology.

Together, these results support a causal relationship between TBI and acceleration of $A \beta$ and tau pathologies. Our mouse model is the first small-animal model, of which we are aware, that reliably and rapidly reproduces these key features of acute human post-TBI A $\beta$ and tau pathologies. This could be attributable to a number of reasons. First, previous TBI models using transgenic mice only used those that overexpress either mutated forms of APP or tau, not both (Smith et al., 1998; Uryu et al., 2002; Yoshiyama et al., 2005). Second, 3xTG-AD mice also have a knock-in PS1 mutation, which shifts $\mathrm{A} \beta$ accumulation to mostly intracellular (Mastrangelo and Bowers, 2008) and possibly increases tau phosphorylation (Baki et al., 2004; Dewachter et al., 2008). Furthermore, methodological differences between our stereotaxic electromagnetically driven controlled cortical impact device-based protocol and previously used injury paradigms could have resulted in different distributions of axonal injury or other subtle differences in postinjury physiology.

However, there are several limitations of our TBI model. First, this model produces a central contusion and pericontusional axonal injury. Humans often do sustain contusions with pericontusional axonal injury, but many injuries in humans are diffuse or multifocal. Nonetheless, axonal injury appears to be a virtually ubiquitous sequela of TBI (Adams, 1982; Gennarelli et al., 1982; Gennarelli, 1983, 1993; Adams et al., 1984; Blumbergs et al., 1994, 1995; Geddes et al., 2000), and many types of injuries in humans have been reported to result in $\mathrm{A} \beta$ and tau pathology (Roberts et al., 1991; Schmidt et al., 2001; D. H. Smith et al., 2003; Ikonomovic et al., 2004; Uryu et al., 2007; McKee et al., 2009). Injured axons appear to be a major source of $\mathrm{A} \beta$ after TBI in humans (D. H. Smith et al., 2003; Ikonomovic et al., 2004; Uryu et al., 2007; Chen et al., 2009), pigs (Smith et al., 1999; Chen et al., 2004), rats (Iwata et al., 2002), and now mice. Therefore, robust axonal injury and intra-axonal $\mathrm{A} \beta$ accumulation lends support to the validity of our model. An additional mouse injury paradigm such as fluid percussion or impact acceleration injury that produces more diffuse axonal injury will be required to generalize our findings.

Second, most humans with TBI do not have a known genetic predisposition to developing $\mathrm{AD}$-related pathologies, whereas the 3xTg-AD line has three mutations implicated in familial dementia. This limitation applies to this and other mouse models of age-related $\mathrm{AD}$ pathology as well. The introduction of these mutations seems to be required because of fundamental differences between mouse and human coding sequences, differences in gene regulation, the short life span of the mouse, or a combination of these. Mice with human wild-type APP, PS1, and tau alleles "knocked in" to the mouse loci would be useful to differentiate these possibilities.

Third, whereas axonal tau accumulation has been observed in a few cases of acute TBI in humans, the effects of injury severity on axonal tau accumulation, as described in this study, have not been documented. Likewise, the increased somatic tau accumulation in this model is rarely observed in human TBI (Ikonomovic et al., 2004). Thus, the relevance of these pathologies is not known.

Fourth, neither this animal model, nor any other small animal of which we are aware, develops acute posttraumatic extracellular $\mathrm{A} \beta$ plaque pathology. The relative importance of extracellular versus intracellular $A \beta$ pathologies in the setting of TBI is not known. Nonetheless, the opportunity to investigate one form of acute posttraumatic $\mathrm{A} \beta$ pathology, acute posttraumatic tau abnormalities, and the interaction of these two pathologies makes the model presented here a significant advance. Ultimately, full validation will require predictions made based on the model that are subsequently confirmed in humans.

The question of whether these pathologies trigger chronic, progressive neurodegeneration remains to be addressed. Similarly, future studies should be performed to determine whether these $\mathrm{A} \beta$ and tau abnormalities adversely affect behavioral outcomes in 3xTg-AD mice subjected to TBI. If so, preclinical therapeutic trials would be required to determine whether clinically realistic interventions could ameliorate these deficits (Abrahamson et al., 2006; Loane et al., 2009). The long-term goal would be to develop treatments that block the adverse effects of $\mathrm{AD}$-related pathophysiological processes after acute TBI in humans.

Based on our findings, it is most likely that $\mathrm{A} \beta$ does not play a critical role in TBI-induced tau pathology. However, a small fraction of $\mathrm{A} \beta$ remained after $\gamma$-secretase inhibition in injured $3 \times \mathrm{Tg}-\mathrm{AD}$ mice. Thus, there may be minor, yet toxic, $\mathrm{A} \beta$ species that could ultimately affect tau pathology. Additional studies should be performed to identify whether such species exist and whether they do, in fact, accelerate tau pathology in the setting of TBI. Experiments involving $\mathrm{Tau}_{\mathrm{P} 301 \mathrm{~L}}$-only transgenic mice or $3 \times \mathrm{Tg}-\mathrm{AD}, \mathrm{BACE}-/-$ mice subjected to TBI would provide further insights into effects of TBI on tau pathology. If, as seems likely, tau pathology is truly independent of $\mathrm{A} \beta$ in the setting of TBI, the underlying mechanisms will require investigation to elucidate additional therapeutic targets. Possible involvement of GSK3 $\beta$, calpain, JNK, and cdk 5 cascades on tau pathology could be considered (Querfurth and LaFerla, 2010).

Apart from its effects on $A \beta$ production, mutant PS1 has been implicated in other functions such as neuronal calcium dyshomeostasis and regulation of synaptic plasticity (Thinakaran and Parent, 2004; Mattson, 2010). Since dysregulation of calcium signaling is thought to play an important role in glutamate-induced excitotoxicity after brain injury (Arundine and Tymianski, 2004; Szydlowska and Tymianski, 2010), it is possible that the mutant PS1 in the 3xTg-AD mouse model may exacerbate TBI-induced neurodegeneration, in addition to its effects on both $A \beta$ and tau pathologies. Future experiments subjecting PS1 single-transgenic mouse to brain trauma will be required to elucidate its role in the context of TBI.

In conclusion, this controlled cortical impact model using $3 \mathrm{xTg}-\mathrm{AD}$ mice reproduced key features of human post-TBI ADrelated pathology. It will likely allow many mechanistic hypoth- 
eses to be tested and may be useful for preclinical therapeutic development.

\section{References}

Abrahamson EE, Ikonomovic MD, Ciallella JR, Hope CE, Paljug WR, Isanski BA, Flood DG, Clark RS, DeKosky ST (2006) Caspase inhibition therapy abolishes brain trauma-induced increases in Abeta peptide: implications for clinical outcome. Exp Neurol 197:437-450.

Adams JH (1982) Diffuse axonal injury in non-missile head injury. Injury 13:444-445.

Adams JH, Doyle D, Graham DI, Lawrence AE, McLellan DR (1984) Diffuse axonal injury in head injuries caused by a fall. Lancet 2:1420-1422.

Arundine M, Tymianski M (2004) Molecular mechanisms of glutamatedependent neurodegeneration in ischemia and traumatic brain injury. Cell Mol Life Sci 61:657-668.

Baki L, Shioi J, Wen P, Shao Z, Schwarzman A, Gama-Sosa M, Neve R, Robakis NK (2004) PS1 activates PI3K thus inhibiting GSK-3 activity and tau overphosphorylation: effects of FAD mutations. EMBO J 23:2586-2596.

Blumbergs PC, Scott G, Manavis J, Wainwright H, Simpson DA, McLean AJ (1994) Staining of amyloid precursor protein to study axonal damage in mild head injury. Lancet 344:1055-1056.

Blumbergs PC, Scott G, Manavis J, Wainwright H, Simpson DA, McLean AJ (1995) Topography of axonal injury as defined by amyloid precursor protein and the sector scoring method in mild and severe closed head injury. J Neurotrauma 12:565-572.

Bramlett HM, Kraydieh S, Green EJ, Dietrich WD (1997) Temporal and regional patterns of axonal damage following traumatic brain injury: a beta-amyloid precursor protein immunocytochemical study in rats. J Neuropathol Exp Neurol 56:1132-1141.

Brody DL, Mac Donald C, Kessens CC, Yuede C, Parsadanian M, Spinner M, Kim E, Schwetye KE, Holtzman DM, Bayly PV (2007) Electromagnetic controlled cortical impact device for precise, graded experimental traumatic brain injury. J Neurotrauma 24:657-673.

Chen XH, Meaney DF, Xu BN, Nonaka M, McIntosh TK, Wolf JA, Saatman KE, Smith DH (1999) Evolution of neurofilament subtype accumulation in axons following diffuse brain injury in the pig. J Neuropathol Exp Neurol 58:588-596.

Chen XH, Siman R, Iwata A, Meaney DF, Trojanowski JQ, Smith DH (2004) Long-term accumulation of amyloid-beta, beta-secretase, presenilin-1, and caspase- 3 in damaged axons following brain trauma. Am J Pathol 165:357-371.

Chen XH, Johnson VE, Uryu K, Trojanowski JQ, Smith DH (2009) A lack of amyloid beta plaques despite persistent accumulation of amyloid beta in axons of long-term survivors of traumatic brain injury. Brain Pathol 19:214-223.

Christman CW, Grady MS, Walker SA, Holloway KL, Povlishock JT (1994) Ultrastructural studies of diffuse axonal injury in humans. J Neurotrauma 11:173-186

Cirrito JR, May PC, O’Dell MA, Taylor JW, Parsadanian M, Cramer JW, Audia JE, Nissen JS, Bales KR, Paul SM, DeMattos RB, Holtzman DM (2003) In vivo assessment of brain interstitial fluid with microdialysis reveals plaque-associated changes in amyloid-beta metabolism and halflife. J Neurosci 23:8844-8853.

Corsellis JA (1989) Boxing and the brain. BMJ 298:105-109.

Corsellis JA, Brierley JB (1959) Observations on the pathology of insidious dementia following head injury. J Ment Sci 105:714-720.

Czirr E, Leuchtenberger S, Dorner-Ciossek C, Schneider A, Jucker M, Koo EH, Pietrzik CU, Baumann K, Weggen S (2007) Insensitivity to Abeta42-lowering nonsteroidal anti-inflammatory drugs and gammasecretase inhibitors is common among aggressive presenilin-1 mutations. J Biol Chem 282:24504-24513.

Dewachter I, Ris L, Croes S, Borghgraef P, Devijver H, Voets T, Nilius B, Godaux E, Van Leuven F (2008) Modulation of synaptic plasticity and Tau phosphorylation by wild-type and mutant presenilin1. Neurobiol Aging 29:639-652.

Fleminger S, Oliver DL, Lovestone S, Rabe-Hesketh S, Giora A (2003) Head injury as a risk factor for Alzheimer's disease: the evidence 10 years on; a partial replication. J Neurol Neurosurg Psychiatry 74:857-862.

Franklin KB, Paxinos G (1997) The mouse brain in stereotaxic coordinates. London: Academic.

Games D, Adams D, Alessandrini R, Barbour R, Berthelette P, Blackwell C,
Carr T, Clemens J, Donaldson T, Gillespie F, Guido, T, Hagopian S, Johnson-Wood K, Khan K, Lee M, Leibowitz P, Lieberburg I, Little S, Masliah E, McConlogue, et al. (1995) Alzheimer-type neuropathology in transgenic mice overexpressing V717F beta-amyloid precursor protein. Nature 373:523-527.

Geddes JF, Vowles GH, Robinson SF, Sutcliffe JC (1996) Neurofibrillary tangles, but not Alzheimer-type pathology, in a young boxer. Neuropathol Appl Neurobiol 22:12-16.

Geddes JF, Vowles GH, Nicoll JA, Revesz T (1999) Neuronal cytoskeletal changes are an early consequence of repetitive head injury. Acta Neuropathol 98:171-178.

Geddes JF, Whitwell HL, Graham DI (2000) Traumatic axonal injury: practical issues for diagnosis in medicolegal cases. Neuropathol Appl Neurobiol 26:105-116.

Gennarelli TA (1983) Head injury in man and experimental animals: clinical aspects. Acta Neurochir Suppl (Wien) 32:1-13.

Gennarelli TA (1993) Mechanisms of brain injury. J Emerg Med 11 [Suppl 1]:5-11.

Gennarelli TA, Thibault LE, Adams JH, Graham DI, Thompson CJ, Marcincin RP (1982) Diffuse axonal injury and traumatic coma in the primate. Ann Neurol 12:564-574.

Gentleman SM, Nash MJ, Sweeting CJ, Graham DI, Roberts GW (1993) Beta-amyloid precursor protein (beta APP) as a marker for axonal injury after head injury. Neurosci Lett 160:139-144.

Gotz J, Chen F, van Dorpe J, Nitsch RM (2001) Formation of neurofibrillary tangles in P3011 tau transgenic mice induced by Abeta 42 fibrils. Science 293:1491-1495.

Grady MS, McLaughlin MR, Christman CW, Valadka AB, Fligner CL, Povlishock JT (1993) The use of antibodies targeted against the neurofilament subunits for the detection of diffuse axonal injury in humans. J Neuropathol Exp Neurol 52:143-152.

Graham DI, Gentleman SM, Lynch A, Roberts GW (1995) Distribution of beta-amyloid protein in the brain following severe head injury. Neuropathol Appl Neurobiol 21:27-34.

Grimwood S, Hogg J, Jay MT, Lad AM, Lee V, Murray F, Peachey J, Townend T, Vithlani M, Beher D, Shearman MS, Hutson PH (2005) Determination of guinea-pig cortical gamma-secretase activity ex vivo following the systemic administration of a gamma-secretase inhibitor. Neuropharmacology 48:1002-1011.

Hurtado DE, Molina-Porcel L, Iba M, Aboagye AK, Paul SM, Trojanowski JQ, Lee VM (2010) A $\{$ beta $\}$ accelerates the spatiotemporal progression of tau pathology and augments tau amyloidosis in an Alzheimer mouse model. Am J Pathol 177:1977-1988.

Ikonomovic MD, Uryu K, Abrahamson EE, Ciallella JR, Trojanowski JQ, Lee VM, Clark RS, Marion DW, Wisniewski SR, DeKosky ST (2004) Alzheimer's pathology in human temporal cortex surgically excised after severe brain injury. Exp Neurol 190:192-203.

Iwata A, Chen XH, McIntosh TK, Browne KD, Smith DH (2002) Long-term accumulation of amyloid-beta in axons following brain trauma without persistent upregulation of amyloid precursor protein genes. J Neuropathol Exp Neurol 61:1056-1068.

Johnson-Wood K, Lee M, Motter R, Hu K, Gordon G, Barbour R, Khan K, Gordon M, Tan H, Games D, Lieberburg I, Schenk D, Seubert P, McConlogue L (1997) Amyloid precursor protein processing and A beta42 deposition in a transgenic mouse model of Alzheimer disease. Proc Natl Acad Sci U S A 94:1550-1555.

Kang JE, Cirrito JR, Dong H, Csernansky JG, Holtzman DM (2007) Acute stress increases interstitial fluid amyloid-beta via corticotropin-releasing factor and neuronal activity. Proc Natl Acad Sci U S A 104:10673-10678.

Lewis J, Dickson DW, Lin WL, Chisholm L, Corral A, Jones G, Yen SH, Sahara N, Skipper L, Yager D, Eckman C, Hardy J, Hutton M, McGowan E (2001) Enhanced neurofibrillary degeneration in transgenic mice expressing mutant tau and APP. Science 293:1487-1491.

Loane DJ, Pocivavsek A, Moussa CE, Thompson R, Matsuoka Y, Faden AI, Rebeck GW, Burns MP (2009) Amyloid precursor protein secretases as therapeutic targets for traumatic brain injury. Nat Med 15:377-379.

Mac Donald CL, Dikranian K, Song SK, Bayly PV, Holtzman DM, Brody DL (2007a) Detection of traumatic axonal injury with diffusion tensor imaging in a mouse model of traumatic brain injury. Exp Neurol 205:116-131.

Mac Donald CL, Dikranian K, Bayly P, Holtzman D, Brody D (2007b) Diffusion tensor imaging reliably detects experimental traumatic ax- 
onal injury and indicates approximate time of injury. J Neurosci 27:11869-11876.

Marmarou CR, Walker SA, Davis CL, Povlishock JT (2005) Quantitative analysis of the relationship between intra-axonal neurofilament compaction and impaired axonal transport following diffuse traumatic brain injury. J Neurotrauma 22:1066-1080.

Mastrangelo MA, Bowers WJ (2008) Detailed immunohistochemical characterization of temporal and spatial progression of Alzheimer's diseaserelated pathologies in male triple-transgenic mice. BMC Neurosci 9:81.

Mattson MP (2010) ER calcium and Alzheimer's disease: in a state of flux. Sci Signal 3:pe10.

McKee AC, Cantu RC, Nowinski CJ, Hedley-Whyte ET, Gavett BE, Budson AE, Santini VE, Lee HS, Kubilus CA, Stern RA (2009) Chronic traumatic encephalopathy in athletes: progressive tauopathy after repetitive head injury. J Neuropathol Exp Neurol 68:709-735.

Mercken M, Vandermeeren M, Lubke U, Six J, Boons J, Van de Voorde A, Martin JJ, Gheuens J (1992) Monoclonal antibodies with selective specificity for Alzheimer Tau are directed against phosphatase-sensitive epitopes. Acta Neuropathol 84:265-272.

Mortimer JA, van Duijn CM, Chandra V, Fratiglioni L, Graves AB, Heyman A, Jorm AF, Kokmen E, Kondo K, Rocca WA, Shalat SL, Soininen H, Hofman A (1991) Head trauma as a risk factor for Alzheimer's disease: a collaborative re-analysis of case-control studies. EURODEM Risk Factors Research Group. Int J Epidemiol 20 [Suppl 2]:S28-S35.

Mouton PR, Gokhale AM, Ward NL, West MJ (2002) Stereological length estimation using spherical probes. J Microsc 206:54-64.

Nemetz PN, Leibson C, Naessens JM, Beard M, Kokmen E, Annegers JF, Kurland LT (1999) Traumatic brain injury and time to onset of Alzheimer's disease: a population-based study. Am J Epidemiol 149:32-40.

Oddo S, Caccamo A, Shepherd JD, Murphy MP, Golde TE, Kayed R, Metherate R, Mattson MP, Akbari Y, LaFerla FM (2003) Triple-transgenic model of Alzheimer's disease with plaques and tangles: intracellular Abeta and synaptic dysfunction. Neuron 39:409-421.

Oddo S, Billings L, Kesslak JP, Cribbs DH, LaFerla FM (2004) Abeta immunotherapy leads to clearance of early, but not late, hyperphosphorylated tau aggregates via the proteasome. Neuron 43:321-332.

Oddo S, Caccamo A, Smith IF, Green KN, LaFerla FM (2006) A dynamic relationship between intracellular and extracellular pools of Abeta. Am J Pathol 168:184-194.

Olson RE, Copeland RA, Seiffert D (2001) Progress towards testing the amyloid hypothesis: inhibitors of APP processing. Curr Opin Drug Discov Dev 4:390-401.

Perez M, Ribe E, Rubio A, Lim F, Moran MA, Ramos PG, Ferrer I, Isla MT, Avila J (2005) Characterization of a double (amyloid precursor proteintau) transgenic: tau phosphorylation and aggregation. Neuroscience 130:339-347.

Planel E, Miyasaka T, Launey T, Chui DH, Tanemura K, Sato S, Murayama O, Ishiguro K, Tatebayashi Y, Takashima A (2004) Alterations in glucose metabolism induce hypothermia leading to tau hyperphosphorylation through differential inhibition of kinase and phosphatase activities: implications for Alzheimer's disease. J Neurosci 24:2401-2411.

Plassman BL, Havlik RJ, Steffens DC, Helms MJ, Newman TN, Drosdick D, Phillips C, Gau BA, Welsh-Bohmer KA, Burke JR, Guralnik JM, Breitner JC (2000) Documented head injury in early adulthood and risk of Alzheimer's disease and other dementias. Neurology 55:1158-1166.

Povlishock JT, Christman CW (1995) The pathobiology of traumatically induced axonal injury in animals and humans: a review of current thoughts. J Neurotrauma 12:555-564.

Querfurth HW, LaFerla FM (2010) Alzheimer's disease. N Engl J Med 362:329-344.

Roberts GW, Allsop D, Bruton C (1990) The occult aftermath of boxing. J Neurol Neurosurg Psychiatry 53:373-378.

Roberts GW, Gentleman SM, Lynch A, Graham DI (1991) beta A4 amyloid protein deposition in brain after head trauma. Lancet 338:1422-1423.

Roberts GW, Gentleman SM, Lynch A, Murray L, Landon M, Graham DI (1994) Beta amyloid protein deposition in the brain after severe head injury: implications for the pathogenesis of Alzheimer's disease. J Neurol Neurosurg Psychiatry 57:419-425.

Schmidt ML, Zhukareva V, Newell KL, Lee VM, Trojanowski JQ (2001) Tau isoform profile and phosphorylation state in dementia pugilistica recapitulate Alzheimer's disease. Acta Neuropathol 101:518-524.

Seiffert D, Mitchell T, Stern AM, Roach A, Zhan Y, Grzanna R (2000) Positive-negative epitope-tagging of beta amyloid precursor protein to identify inhibitors of A beta processing. Brain Res Mol Brain Res $84: 115-126$.

Selkoe DJ (2001) Alzheimer's disease: genes, proteins, and therapy. Physiol Rev 81:741-766.

Sherriff FE, Bridges LR, Sivaloganathan S (1994) Early detection of axonal injury after human head trauma using immunocytochemistry for betaamyloid precursor protein. Acta Neuropathol 87:55-62.

Smith C, Graham DI, Murray LS, Nicoll JA (2003) Tau immunohistochemistry in acute brain injury. Neuropathol Appl Neurobiol 29:496-502.

Smith DH, Nakamura M, McIntosh TK, Wang J, Rodriguez A, Chen XH, Raghupathi R, Saatman KE, Clemens J, Schmidt ML, Lee VM, Trojanowski JQ (1998) Brain trauma induces massive hippocampal neuron death linked to a surge in beta-amyloid levels in mice overexpressing mutant amyloid precursor protein. Am J Pathol 153:1005-1010.

Smith DH, Chen XH, Nonaka M, Trojanowski JQ, Lee VM, Saatman KE, Leoni MJ, Xu BN, Wolf JA, Meaney DF (1999) Accumulation of amyloid beta and tau and the formation of neurofilament inclusions following diffuse brain injury in the pig. J Neuropathol Exp Neurol 58:982-992.

Smith DH, Chen XH, Iwata A, Graham DI (2003) Amyloid beta accumulation in axons after traumatic brain injury in humans. J Neurosurg 98:1072-1077.

Stone JR, Singleton RH, Povlishock JT (2000) Antibodies to the C-terminus of the beta-amyloid precursor protein (APP): a site specific marker for the detection of traumatic axonal injury. Brain Res 871:288-302.

Stone JR, Singleton RH, Povlishock JT (2001) Intra-axonal neurofilament compaction does not evoke local axonal swelling in all traumatically injured axons. Exp Neurol 172:320-331.

Szydlowska K, Tymianski M (2010) Calcium, ischemia and excitotoxicity. Cell Calcium 47:122-129.

Thinakaran G, Parent AT (2004) Identification of the role of presenilins beyond Alzheimer's disease. Pharmacol Res 50:411-418.

Tokuda T, Ikeda S, Yanagisawa N, Ihara Y, Glenner GG (1991) Reexamination of ex-boxers' brains using immunohistochemistry with antibodies to amyloid beta-protein and tau protein. Acta Neuropathol $82: 280-285$.

Uryu K, Laurer H, McIntosh T, Pratico D, Martinez D, Leight S, Lee VM, Trojanowski JQ (2002) Repetitive mild brain trauma accelerates Abeta deposition, lipid peroxidation, and cognitive impairment in a transgenic mouse model of Alzheimer amyloidosis. J Neurosci 22:446-454.

Uryu K, Chen XH, Martinez D, Browne KD, Johnson VE, Graham DI, Lee VM, Trojanowski JQ, Smith DH (2007) Multiple proteins implicated in neurodegenerative diseases accumulate in axons after brain trauma in humans. Exp Neurol 208:185-192.

Witter MP, Amaral DG (2004) Hippocampal formation. In: The rat nervous system (Paxinos G, ed), pp 635-704. Amsterdam: Elsevier.

Yaghmai A, Povlishock J (1992) Traumatically induced reactive change as visualized through the use of monoclonal antibodies targeted to neurofilament subunits. J Neuropathol Exp Neurol 51:158-176.

Yan P, Bero AW, Cirrito JR, Xiao Q, Hu X, Wang Y, Gonzales E, Holtzman DM, Lee JM (2009) Characterizing the appearance and growth of amyloid plaques in APP/PS1 mice. J Neurosci 29:10706-10714.

Yang T, Arslanova D, Gu Y, Augelli-Szafran C, Xia W (2008) Quantification of gamma-secretase modulation differentiates inhibitor compound selectivity between two substrates Notch and amyloid precursor protein. Mol Brain 1:15.

Yoshiyama Y, Uryu K, Higuchi M, Longhi L, Hoover R, Fujimoto S, McIntosh T, Lee VM, Trojanowski JQ (2005) Enhanced neurofibrillary tangle formation, cerebral atrophy, and cognitive deficits induced by repetitive mild brain injury in a transgenic tauopathy mouse model. J Neurotrauma 22:1134-1141. 